\title{
Seismic geomorphology and stratigraphic trap analyses of the Lower Cretaceous siliciclastic reservoir in the Kopeh Dagh-Amu Darya Basin
}

\author{
Gholamreza Hosseinyar $^{1} \cdot$ Reza Moussavi-Harami $^{1} \cdot$ Iraj Abdollahie Fard $^{2} \cdot$ Asadollah Mahboubi $^{1}$. \\ Rooholah Noemani Rad ${ }^{2}$
}

Received: 9 February 2018 / Published online: 8 August 2019

(c) The Author(s) 2019

\begin{abstract}
Lower Cretaceous Shurijeh-Shatlyk Formations host some of the main reservoirs in the Kopeh Dagh-Amu Darya Basin. Exploration in this area so far has focused on the development of structural traps, but recognition of stratigraphic traps in this area is of increasing importance. Integration of 3D seismic data with borehole data from thirteen wells and five outcrop sections was used to identify potential reservoir intervals and survey the hydrocarbon trap types in the East Kopeh Dagh Foldbelt (NE Iran). Analyses of horizontal slices indicated that the lower Shurijeh was deposited in a braided fluvial system. Generally, three types of channel were identified in the lower Shurijeh Formation: type 1, which is low-sinuosity channels interpreted to be filled with non-reservoir fine-grained facies; type 2, which is a moderately sinuous sand-filled channel with good prospectively; and type 3, which is narrow, high sinuosity channel filled with fine-grained sediments. Results indicate that upper Shurijeh-Shatlyk Formations were deposited in fluvial to delta and shallow marine environments. The identified delta forms the second reservoir zone in the Khangiran Field. Study of the stratigraphic aspects of the Shurijeh succession indicates that both lower and upper Shurijeh reservoirs are stratigraphic reservoir traps that improved during folding.
\end{abstract}

Keywords 3D seismic $\cdot$ Fluvial $\cdot$ Stratigraphic trap $\cdot$ Cretaceous $\cdot$ Kopeh Dagh $\cdot$ Amu Darya

\section{Introduction}

The Kopeh Dagh-Amu Darya Basin (KDADB) is a large and producing world-class hydrocarbon province (Fig. 1a, Kryuchkov 1996; Ulmishek 2004; Brunet et al. 2017). The KDADB contains several hydrocarbon-bearing fields on the Turkmenistan, NE Iran, Uzbekistan and north of Afghanistan most of which are gas fields (Fig. 1a). The main explored fields are Galkynysh (or Yolotan-Osman, the largest gas field in the basin), Dauletabad, Shaltyk, Bayram-Ali, Islim, Gazli, Setalantepe, Shurtan, Khangiran and Gonbadli (Fig. 1a; Afshar-Harb 1979; Moussavi-Harami and

Edited by Jie Hao

Reza Moussavi-Harami

moussavi@um.ac.ir

1 Department of Geology, Faculty of Science, Ferdowsi University of Mashhad, Mashhad 91775-1436, Iran

2 Geophysics Department, NIOC Exploration Directorate, Tehran 19395-6669, Iran
Brenner 1992; Ulmishek 2004; Klett et al. 2006; Yixin et al. 2015; Hosseinyar et al. 2018).

The KDADB is bounded on the north side by the Kyzylkum high with Paleozoic metamorphic and igneous rocks. To the southeast, it adjoins the Afghan-Tajik Basin which was connected to the KDADB from the Early Mesozoic until Miocene times (Ulmishek 2004). The South Caspian Basin forms the western boundary of the basin. To the south, it is bounded by the Palaeo-Tethys suture zone and Bande Turkestan Foldbelt (Fig. 1). The Palaeo-Tethys suture zone occluded on the Cimmerian oceanic closure between Eurasia with Iran and Afghan blocks. It separates the Neo-Tethys Ocean from the KDADB (Robert et al. 2014; Siehl 2015).

There are ten hydrocarbon plays in the KDADB (Yixin et al. 2015), of which the main regional reservoirs include Lower-Middle Jurassic siliciclastics, Upper Jurassic carbonate, Lower Cretaceous siliciclastic rocks and Upper Cretaceous sandstones (Brookfield and Hashmat 2001; Ulmishek 2004). Only Upper Jurassic carbonates and Lower Cretaceous siliciclastic rocks are identified as reservoirs in the Kopeh Dagh range (Afshar-Harb 1979, 1982; Moussavi-Harami and Brenner 1992; Kavoosi et al. 2009; 

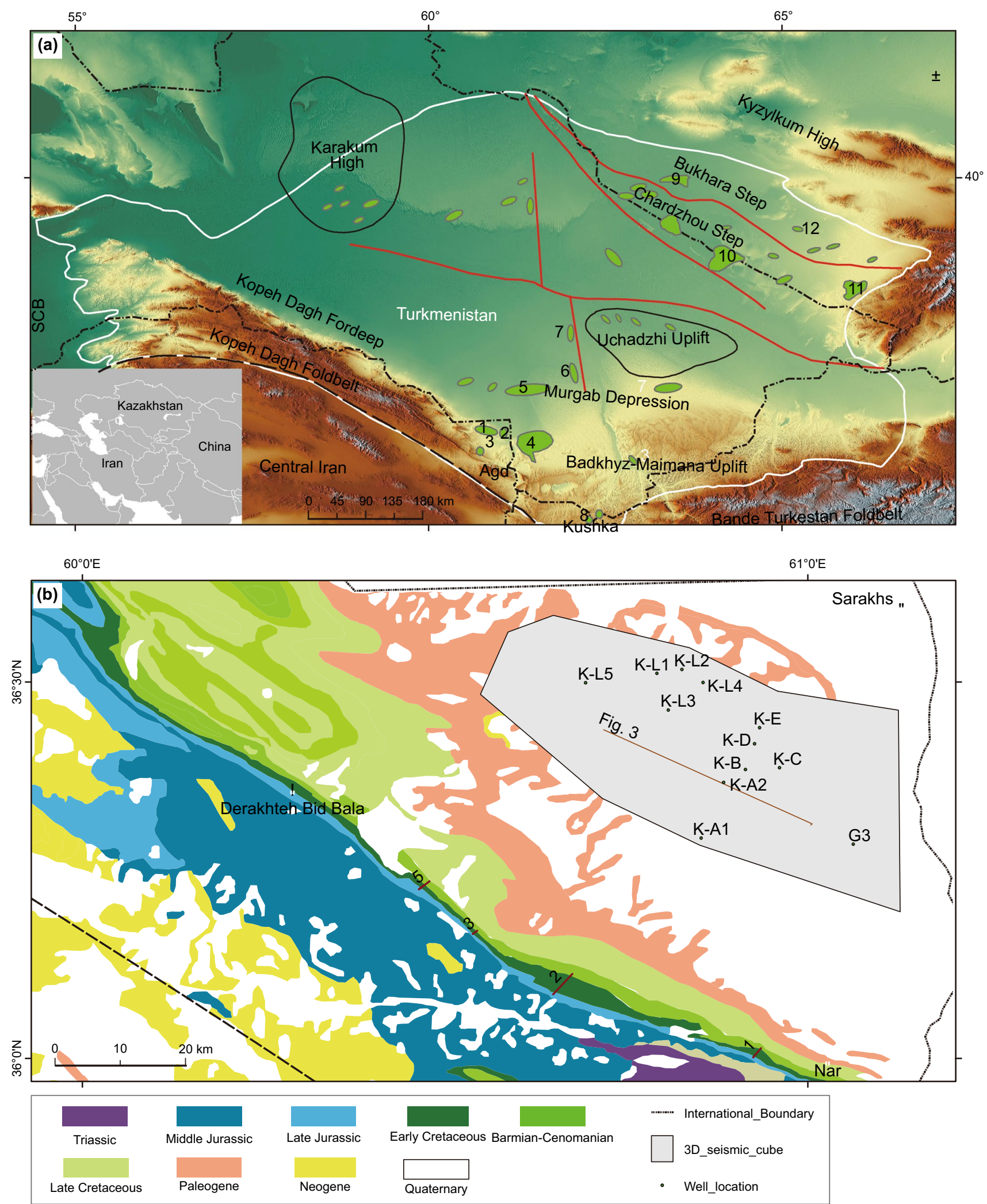

Fig. 1 a Major tectonic features of KDADB (modified after Stocklin 1977; Berberian and King 1981; Ulmishek 2004; Klett et al. 2006). MKF: Main Kopeh Dagh Fault; Agd: Aghdarband erosional window; SCB: South Caspian Basin. Major gas fields: 1: Khangiran; 2: Gonbadli; 3: Toos; 4: Dauletabad; 5: Shaltyk; 6: Bayram-Ali; 7: May; 8: Islim; 9: Gazli; 10: Dengizkul; 11: Shurtan; 12: Setalantepe. b Location map of 3D seismic survey, well locations and stratigraphic outcrop sections presented in this article. Stratigraphic sections: 1: Shurijeh; 2: Anjeer-Bulagh; 3: Mozduran Pass; 4: East Qorqoreh; 5: West Qorqoreh 
Kavoosi 2014). Shale and coal layers of the Lower-Middle Jurassic succession (Fig. 2) are considered as source rock in the KDADB (Kalantari 1987; Ulmishek 2004; Klett et al. 2006; Robert et al. 2014; Saadati et al. 2016). Based on molecular and isotopic analysis, accumulated hydrocarbons in the Lower Cretaceous and Upper Jurassic reservoirs (Fig. 2) are genetically thermogenic in the eastern Kopeh Dagh basin, derived mainly from source rocks with kerogen types III and II (Saadati et al. 2016).

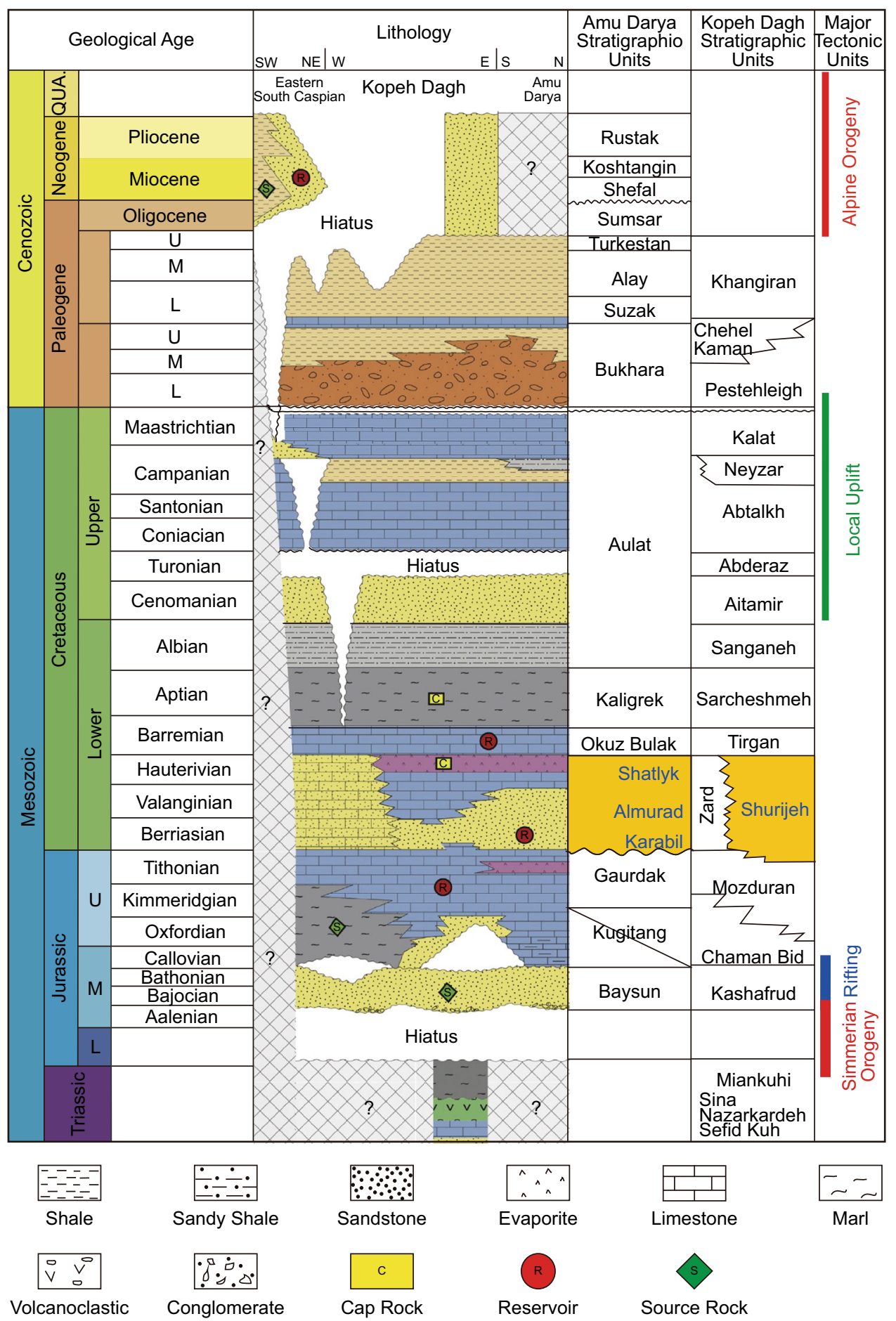

Fig. 2 Regional Mesozoic stratigraphic column of the Kopeh Dagh and Amu Darya Basin (Modified after Robert et al. 2014 and Klett et al. 2006) 
The Lower Cretaceous succession (the main target of this study) has the main productive reservoirs in the Khangiran, Gonbadli and Dauletabad gas fields (Ulmishek 2004). This non-marine to deltaic and marine siliciclastic succession is known as the Shurijeh Formation in the Kopeh Dagh and Karabil, Almurad and Shatlyk (Qezeltash) Formations in the Amu Darya range (Fig. 2). In this study, we use both equivalent Formations together [Shurijeh and Shatlyk (instead of Karabil, Almurad and Shatlyk)] to avoid the complexity of different Formation names in Iran, Turkmenistan and surrounding area.

Most of the hydrocarbon fields in the KDADB are considered as structural traps, especially in the Khangiran and Gonbadli fields (Afshar-Harb 1979; Moussavi-Harami and Brenner 1992; Ulmishek 2004). The Lower Cretaceous succession reveals considerable lateral facies variations in the basin (Moussavi-Harami and Brenner 1992, 1993; Ulmishek 2004; Klett et al. 2006; Mortazavi et al. 2013a, b; Hosseinyar et al. 2018). On the other hand, recent studies and exploration of new reef reservoirs (e.g. in Galkynysh Field) in the basin are showing importance of stratigraphic reservoirs in exploration (Yixin et al. 2015; Brunet et al. 2017).

The Hauterivian Sandstone Bed forms a reservoir zone in most gas fields of the KDADB, especially in the Murgab Depression (Fig. 1) where 90 percent of explored gas reserves are produced from these sandstones (Kryuchkov 1996; Ulmishek 2004). The Khangiran Field is unique in the basin; it has formed distinct lower and upper reservoir zones in the Lower Cretaceous rocks (Hosseinyar et al. 2018). The main objective of this study is to investigate the stratigraphic aspects of the Lower Cretaceous Shurijeh-Shatlyk reservoirs of the KDADB, focusing on the eastern Kopeh Dagh Foldbelt. In fluvial reservoir analysis, interpretation of fluvial style, shape, arrangement and distinction of sand-filled from mud-filled channels is the key elements for recognition of reservoir architecture (Carter 2003; Davies et al. 2007, b; Posamentier et al. 2007; Brown 2011; Miall 2014; Torrado et al. 2014). In addition, understanding depositional systems in plain view is very important for prediction of sandstone reservoirs, because the palaeogeomorphology and sediment supply can control patterns of their spatial dispersal (Posamentier et al. 2007; Zeng 2010; Zhu et al. 2013; Chinwuko et al. 2015; Eichkitz et al. 2015; Wang et al. 2016). Therefore, we use seismic geomorphology techniques to evaluate the geological features and ancient buried geomorphological surfaces. Then, the results are integrated with borehole data, as another critical step, for analyses of lithological and sedimentological aspects for interpretation.

\section{Geologic setting}

The study area is located in the eastern Kopeh Dagh Foldbelt in the south of the KDADB. The present NW-SE to WNW-ESE elongated shape and structural features of the basin is the result of various orogenies from Paleozoic to the present (Alavi et al. 1997; Zanchetta et al. 2013; Robert et al. 2014; Siehl 2015; Zanchi et al. 2016; Brunet et al. 2017). The main folding and thrusting of sediments occurred during the Alpine (Neogene-Quaternary) orogenic phases (Ramazani-Oomali et al. 2008; Robert et al. 2014; Jolivet 2015; Siehl 2015; Brunet et al. 2017).

The oldest rocks in the region are Devonian to Triassic in age (Fig. 2), which were deformed by the Variscan and Early Cimmerian orogenies, and exposed in the Aghdarband erosional window and north of Afghanistan (Afshar-Harb 1979; Ruttner 1991, 1993; Garzanti and Gaetani 2002; Taheri et al. 2009; Zanchi 2009, 2016; Zanchetta et al. 2013; Siehl 2015).

About 6 (in the margins) to 15 (in the center) $\mathrm{km}$ of sediments have been deposited since the Paleozoic in the KDADB (Siehl 2015; Brunet et al. 2017). The relatively continuous deposition of sedimentary rocks began during Middle Jurassic rifting through to Miocene time (Moussavi-Harami and Brenner 1992; Ulmishek 2004; Klett et al. 2006). However, there have been several hiatuses within the Jurassic-Paleocene sequence in the basin (Fig. 2, and see Robert et al. 2014; Brunet et al. 2017; Hosseinyar et al. 2018).

During the Middle-Upper Jurassic marine transgression, a carbonate platform expanded in the basin and Middle Jurassic siliciclastic deposits is overlain unconformably by Callovian-Tithonian (Mozduran-Kugitang Formations) carbonate rocks. Mozduran-Kugitang Formations were deposited in a carbonate platform within a shallow-water carbonate shelf (on the northern and western parts) separated by a semicircular barrier reef complex (on the eastern and central parts) from deep marine environments toward the south and southeast of the basin. Patch reefs were identified in the Khangiran Field and along the outcrop belt to the south (Robert et al. 2014; Hosseinyar et al. 2018). The carbonate rocks are overlaid by more than $900 \mathrm{~m}$ of evaporites of the Kimmeridgian-Tithonian Gaurdak Formation in the Murgab Depression and North Afghanistan (Fig. 2). The salt and anhydrite of the Gaurdak Formation is absent in the Kopeh Dagh Foldbelt where the Mozduran Formation is directly overlain by Lower Cretaceous siliciclastic rocks of the Shurijeh Formation (Moussavi-Harami and Brenner 1990; ZandMoghadam et al. 2016; Aghaei et al. 2018). Deposition of carbonate sediments continued until the Tithonian in the Kopeh Dagh Foldbelt (Kavoosi et al. 2009).

During the Late Jurassic-Early Cretaceous, a widespread regional regression took place in the KDADB 
(Thomas et al. 1999; Golonka 2004) and red bed siliciclastics of the Shurijeh-Shatlyk Formations were deposited in non-marine to delta and shallow marine environments (Moussavi-Harami et al. 2009; Mortazavi et al. 2013a, b). The siliciclastic sandstone, siltstone and claystone grade into mixed salt-siliciclastic sediments to the east (Ulmishek 2004). The Late Jurassic-Early Cretaceous regression affected the north of Afghanistan too (Brookfield and Hashmat 2001; Klett et al. 2006). Lower Cretaceous siliciclastic rocks change gradually into conglomeratic lithofacies toward the south and southeast of the basin (Moussavi-Harami and Brenner 1992; Brookfield and Hashmat 2001; Klett et al. 2006).

There are limited studies of the sedimentological characteristics of the Shurijeh-Shatlyk Formations particularly on the eastern part of the KDADB. However, recent studies of the Kopeh Dagh Foldbelt have indicated that the Shurijeh Formation derived from metamorphic, igneous and sedimentary sources exposed on the south and SW of the study area and was deposited under arid to semiarid climatic conditions at moderate palaeolatitudes $\left(30^{\circ}-40^{\circ} \mathrm{N}\right)$ (Moussavi-Harami and Brenner 1990, 1992; Thomas et al. 1999; Mortazavi et al. 2013a, b). As time passed, siliciclastic Shurijeh-Shatlyk Formations gradually changed to the calcareous deposits of Barmian-Aptian age (Fig. 2). Marine carbonate and clastic sediments were deposited during the Late Cretaceous in the KDADB and continued with alternation of carbonate, sandstone and gypsum in the Palaeogene and with marine to continental deposits in the Neogene.

The Shurijeh succession is exposed along the outcrop in the south of the Khangiran and Gonbadli gas fields
(Figs. 1b, c). From a stratigraphic view, it is composed of pebbly sandstone, sandstone, siltstone, claystone and shale with thin anhydrite interbeds in the Khangiran and Gonbadli fields, which pass southwards and southeastwards into conglomerate-sandstone facies. Based on previous work and this study, the siliciclastic Shurijeh Formation was deposited in proximal braided rivers with gravely bed load in the lower part and sandstone-shale deposits in fluvial to shoreline and shallow marine environments in the upper part in the outcrop belt (Moussavi-Harami and Brenner 1992, 1993; Mortazavi et al. 2013a, b; Hosseinyar et al. 2018). The thickness of the Shurijeh-Shatlyk Formations increases from North Afghanistan and surrounding area to the central parts of the basin and evaporite facies are deposited in the eastern parts. The thickness of the Shurijeh Formation along the outcrop belt changes from $40 \mathrm{~m}$ in the Nar area to more than $900 \mathrm{~m}$ in the Khor section (to the west; Fig. 1b). It varies between 200 and $380 \mathrm{~m}$ in the Khangiran Field and decreases toward the east to the Gonbadli Field and Badkhyz-Maimana uplift (Fig. 3).

In addition, continental conglomeratic sediments pinch out to the central Kopeh Dagh Foldbelt and change to sabkha, intertidal and shallow marine facies. Moreover, a marine carbonate depositional regime was established for a short period of the time (Valanginian-Hauterivian) in the west and southwest. This marine transgression resulted in the deposition of the carbonate member (Early Hauterivian) of the Almurad Formation (VZG 2004) in western Turkmenistan and Khangiran Field (Klett et al. 2006; Hosseinyar et al. 2018). It reaches to more than $400 \mathrm{~m}$ of wellbedded carbonate in the Khor and Hamam-Ghaleh sections to the west (Fig. 1).

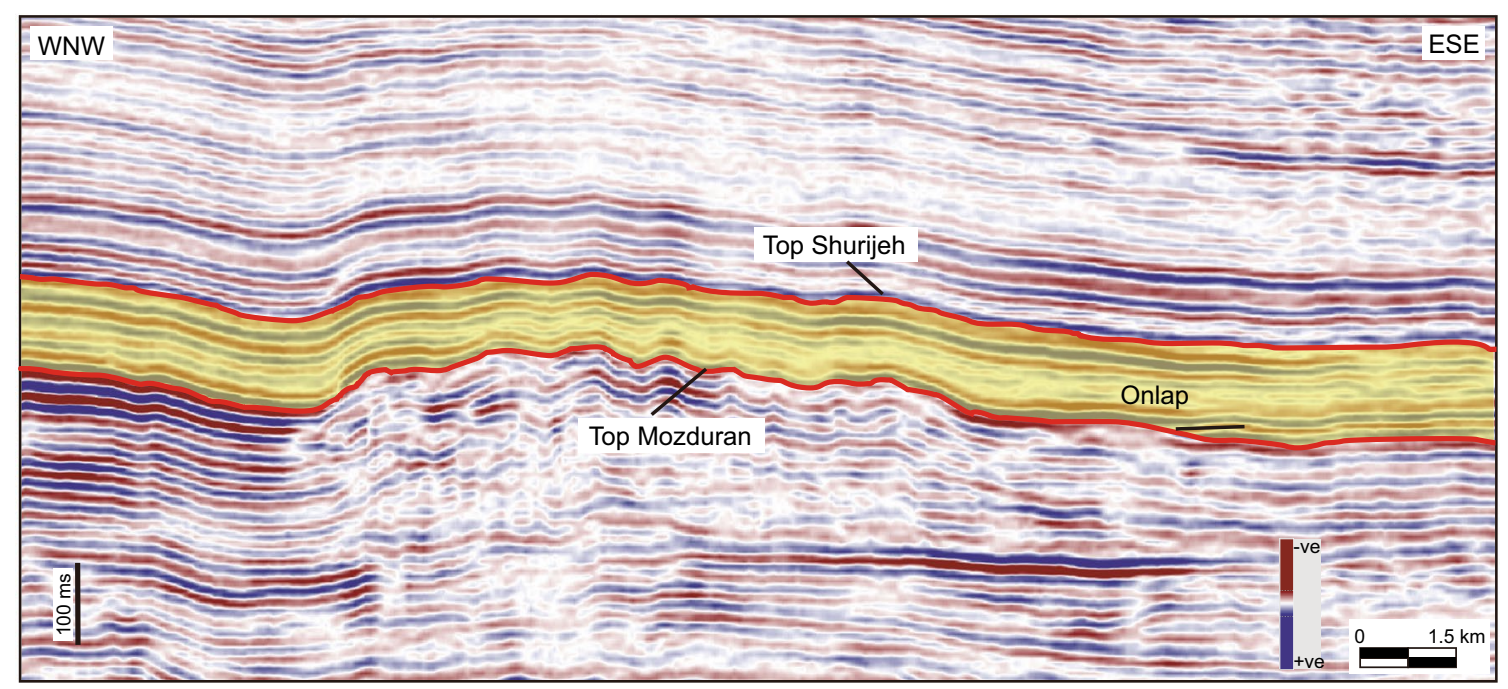

Fig. 3 East-west seismic section showing the onlapping reflectors and thickness variation (increasing toward the west) of the Shurijeh Formation due to the irregular topography. See location in Fig. 1 


\section{Data and methodology}

The data set available includes a 3D time-migrated seismic volume together with borehole data from thirteen wells and five outcropped stratigraphic sections.

The Shurijeh Formation is exposed in the southern part of the study area (Fig. 1c). Stratigraphic sections were measured in the Shurijeh Village, Anjeer-Bulagh, Mozduran Pass, East Qorqoreh and West Qorqoreh (Fig. 1c). Thicknesses of the Shurijeh Formation in these sections are 92, 143, 197, 217 and 286 meters, respectively, from east to the west. Fourteen lithofacies are identified in this study including 11 terrigenous and 3 non-terrigenous lithofacies based on Miall (1985). Description and interpretation of each lithofacies are briefly presented in Table 1 and Fig. 4.

In total, well logs, core and cuttings data from 50 wells have been reviewed, and thirteen wells were selected for detailed analysis (Fig. 1b). Wireline logs including gamma-ray, spontaneous potential, resistivity, density, sonic and neutron are used. Cuttings samples from the Shurijeh Formation were available for all wells, with $1 \mathrm{~m}$ (sometimes $30 \mathrm{~cm}$ ) intervals, and core data were provided from wells KB, KC, KD, KL4 and G3.

The available 3D seismic cube with $25 \times 25$ meters as bin size covers two seismic surveys across an area of $\sim 1000 \mathrm{~km}^{2}$ which were acquired in the late 1990s and early 2010s. All horizons were interpreted on seismic section and beyond classic seismic stratigraphy and analysis, used for extracting geomorphological maps (Zeng and Hentz 2004). Utilization of seismic geomorphology in conjunction with seismic stratigraphy allows stratigraphic geobodies to be extracted from the 3D seismic data. Different seismic attributes are necessary for extracting fluvial sedimentary features (and other possible geobodies) in petroleum exploration studies (Chopra and Marfurt 2007; Davies et al. 2007, b; Posamentier et al. 2007; Brown 2011). In this research, coherency, instantaneous and texture (energy, entropy and homogeneity) attributes were extracted within the interpreted intervals to evaluate geological features and their lateral and vertical changes. Spectral decomposition based on continuous-wavelet transforms (CWTs) was also used in this study and has been applied at frequencies of 5, 10, 14 and $30 \mathrm{~Hz}$.

\section{Results}

\subsection{Well and outcrop-based studies}

Sedimentological studies indicated that the Shurijeh Formation can be subdivided into four lithological units from base to top including (Hosseinyar et al. 2018): Units A and $\mathrm{B}$, as the lower Shurijeh, and Units C and D as the upper Shurijeh Formation.

Unit A this unit is composed of thin shale layers with medium to thick horizontal and planar cross-bedded sandstone lenses on the outcropped sections. Based on petrophysical logs with semi-funnel log motifs [in GR log (Fig. 5)] and cuttings samples, the lithology includes reddish brown shale, claystone to siltstone with white anhydrite nodules. In well $\log$, this unit shows high gamma ray and moderate resistivity values (Fig. 5). The neutron and density log curves are separated, indicating fine-grained facies. Although, total porosity of this unit is relatively good, but effective porosity is near zero (Fig. 5b).

Unit B This unit includes grain-dominated conglomerate layers with thin to medium-bedded pebbly sandstone, siltstone and mudstone interbeds on the outcropped sections. This unit shows blocky or box-like trends in the gamma ray logs (Figs. 5 and 6) which in the subsurface samples (cores and cutting) has predominantly sandstone to microconglomerate facies with intercalations of thin claystones and siltstone layers. In well $\operatorname{logs}$, resistivity increased and the neutron and density log curves coincide with each other (Fig. 5). In wells KL1 and KL2, the GR signatures in the upper part of the blocky trend with siltstones to silty shale facies (Fig. 5), interpreted as lateral accretion deposits (cf. Miall 2014). The upper part of Unit B (in well logs) is determined by high gamma-ray content with a serrated trend and separation of density and neutron logs (Fig. 5). This is interpreted as flood plain or coastal plain fine-grained deposits.

Unit $C$ This unit is comprised of conglomerate and sandstone layers that mostly formed from carbonate and quartz pebbles in the East Qorqoreh and West Qorqoreh sections. In the Khangiran Field (based on cuttings), Unit $C$ includes reddish to brown, fine to medium-grained sandstones with intervals of micro-conglomerate to pebbly sandstone, which changes upward to gypsiferous shale, siltstone and claystone layers (Figs. 5 and 6). Thin anhydrite layers are also present in this unit (Fig. 6). Clasts are mostly limestone fragments and quartz. In well logs, gamma ray and resistivity values are increased, and separation of the neutron and density logs is low (Fig. 5). The variable contents of logs may be related to lithological and probable fluid changes. Unit $\mathrm{C}$ was mainly deposited in the western parts of the study area and thins toward the east in the Anjeer-Bulagh section and disappears in the Gonbadli Field as well as along the outcrop belt in the Shurijeh Village section (Hosseinyar et al. 2018).

Unit D This unit is composed of fine to medium-grained thick to massive sandstones that are covered with green and purple shale layers in all outcropped sections. Calcrete palaeosols are present in the sandstone layers. In the borehole data, the uppermost unit (D) predominantly consists of fine to medium-grained, calcareous gray sandstones alternating 


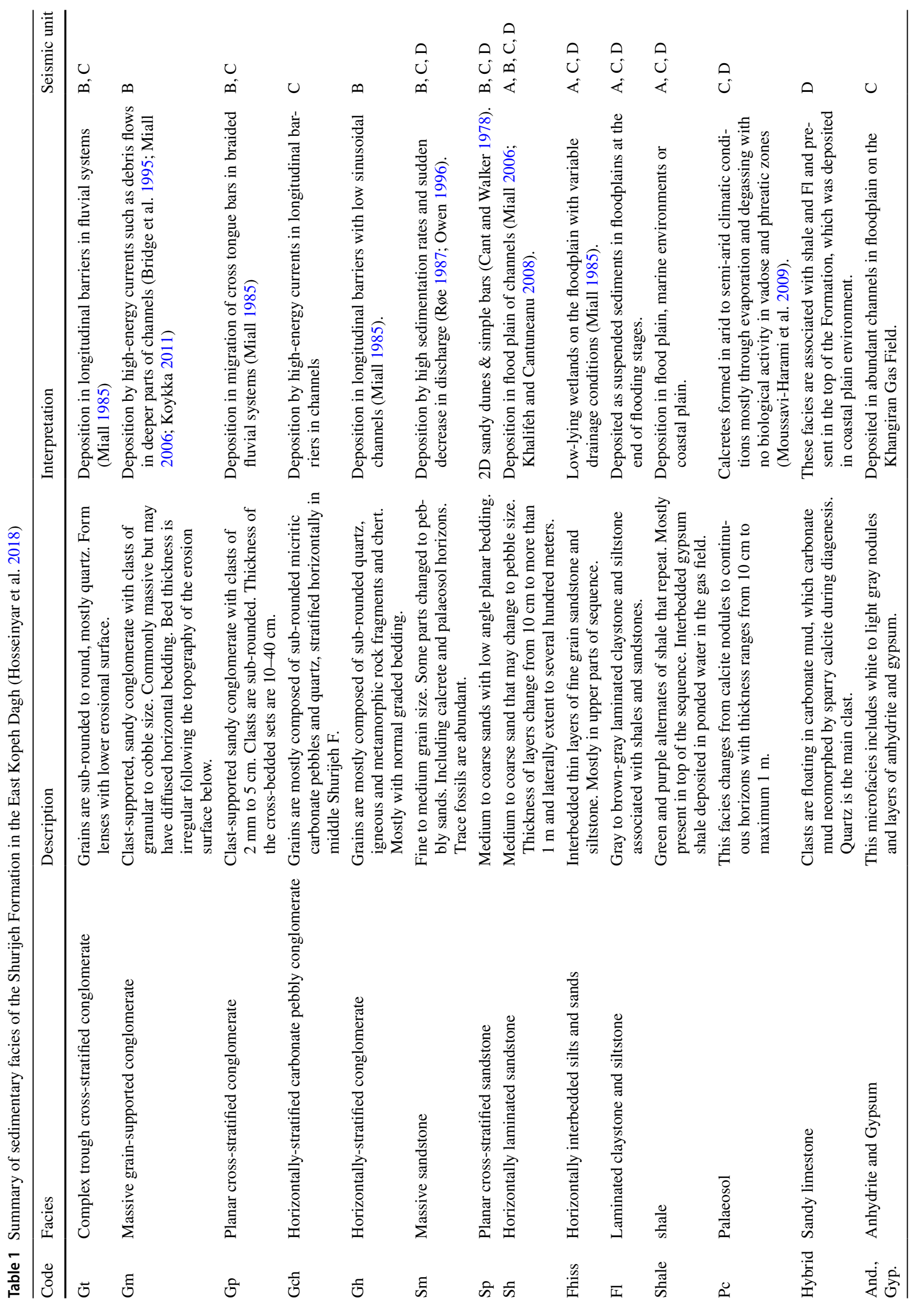



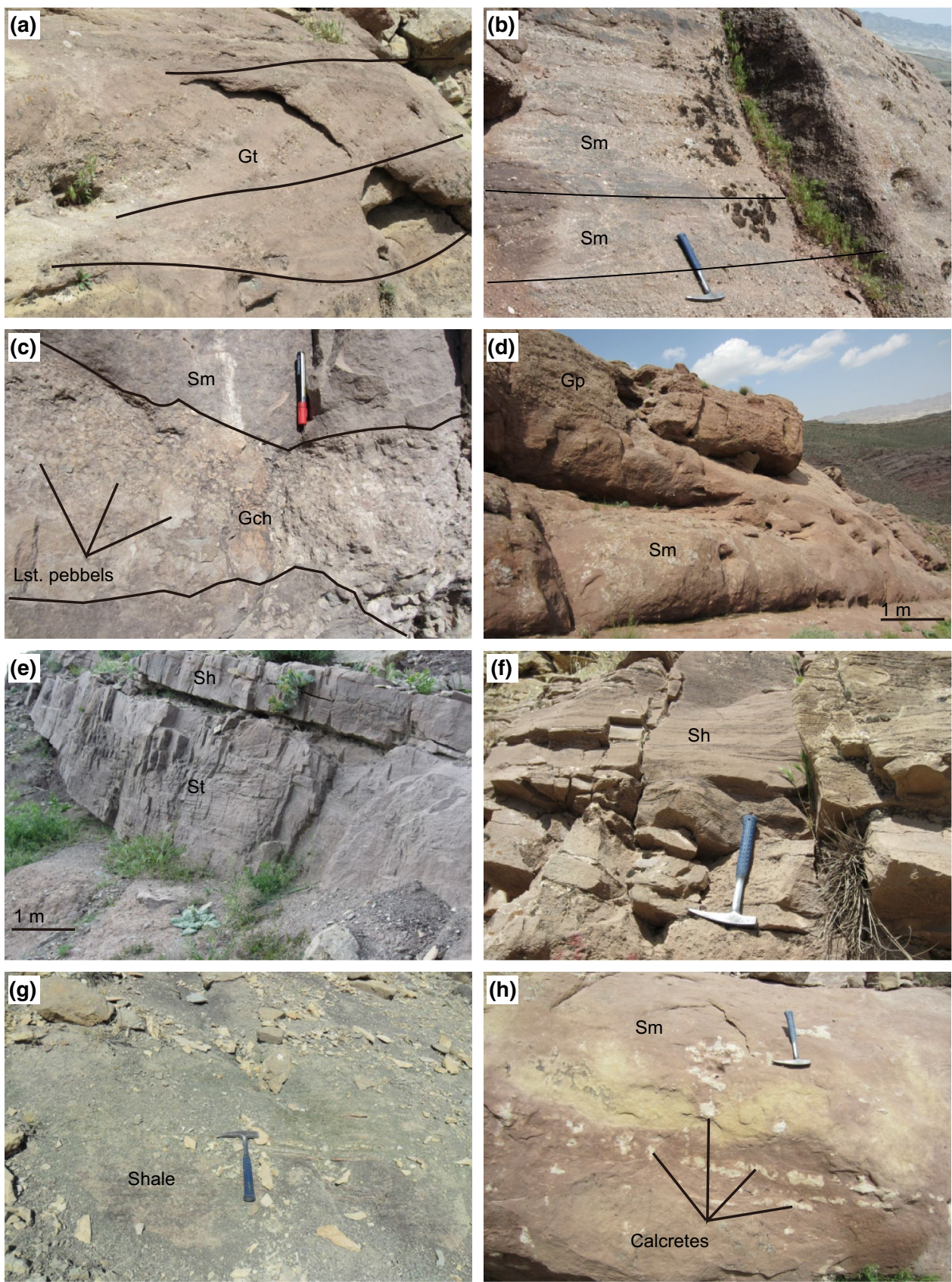

Fig. 4 Representative lithofacies of the Shurijeh Formation. a Complex trough cross-stratified conglomerate (Gt). b Planar cross-stratified conglomerate (Gp) and horizontally-stratified conglomerate (Gh). c Horizontally stratified carbonate pebbly conglomerate (Gch). Lst: Limestone. d Massive pebbly sandstone ( $\mathrm{Sm}$ ) bounded by erosional surface and covered by planar cross-stratified conglomerate (Gp). e Trough cross-stratified sandstone (St) and horizontally laminated sandstone (Sh). f Horizontally laminated sandstones (Sh). g Gypsiferous shale. h Palaeosol

with brown partly gypsiferous claystones and mudstones, light gray calcareous siltstones and a few layers of dark gray pyritic calcareous shale. Different log responses illustrate the sandstone facies in the lower part with low gamma ray and resistivity values and neutron and density log curves coincide, that change to upper high gamma ray and resistivity contents with separated neutron and density log curves (Figs. 5 and 6).

\subsection{Seismic geomorphology}

In total, eight horizons were interpreted on the seismic cube. The lowermost three horizons $\left(\mathrm{A}, \mathrm{B}_{1}\right.$ and $\mathrm{B}_{2}$ ) correspond to the lower Shurijeh Formation and the others to the upper Shurijeh. Calibration of seismic data with wells shows an excellent tie between log lithology and seismic amplitude, enabling the horizontal distribution of 
(a)

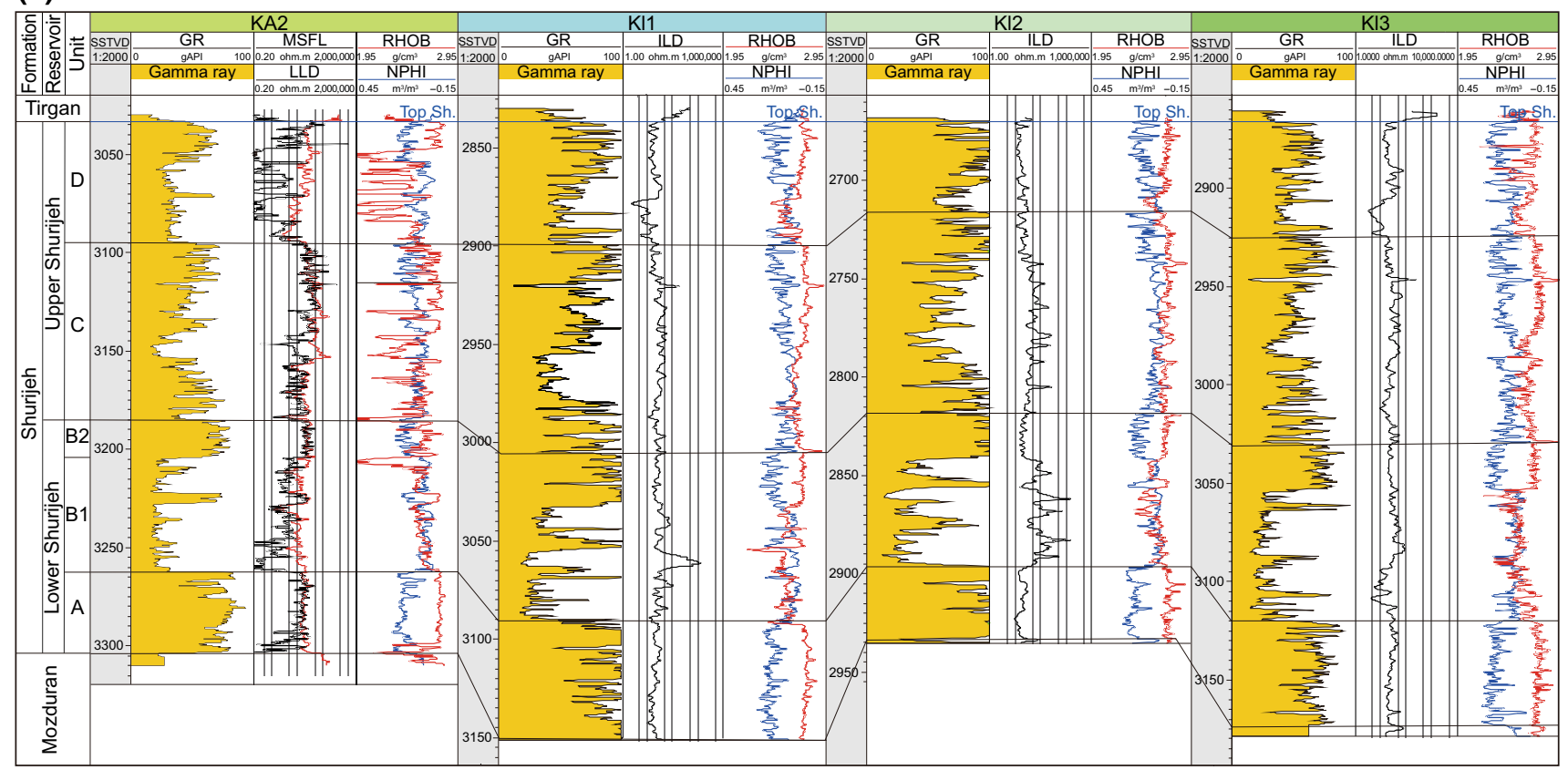

(b)

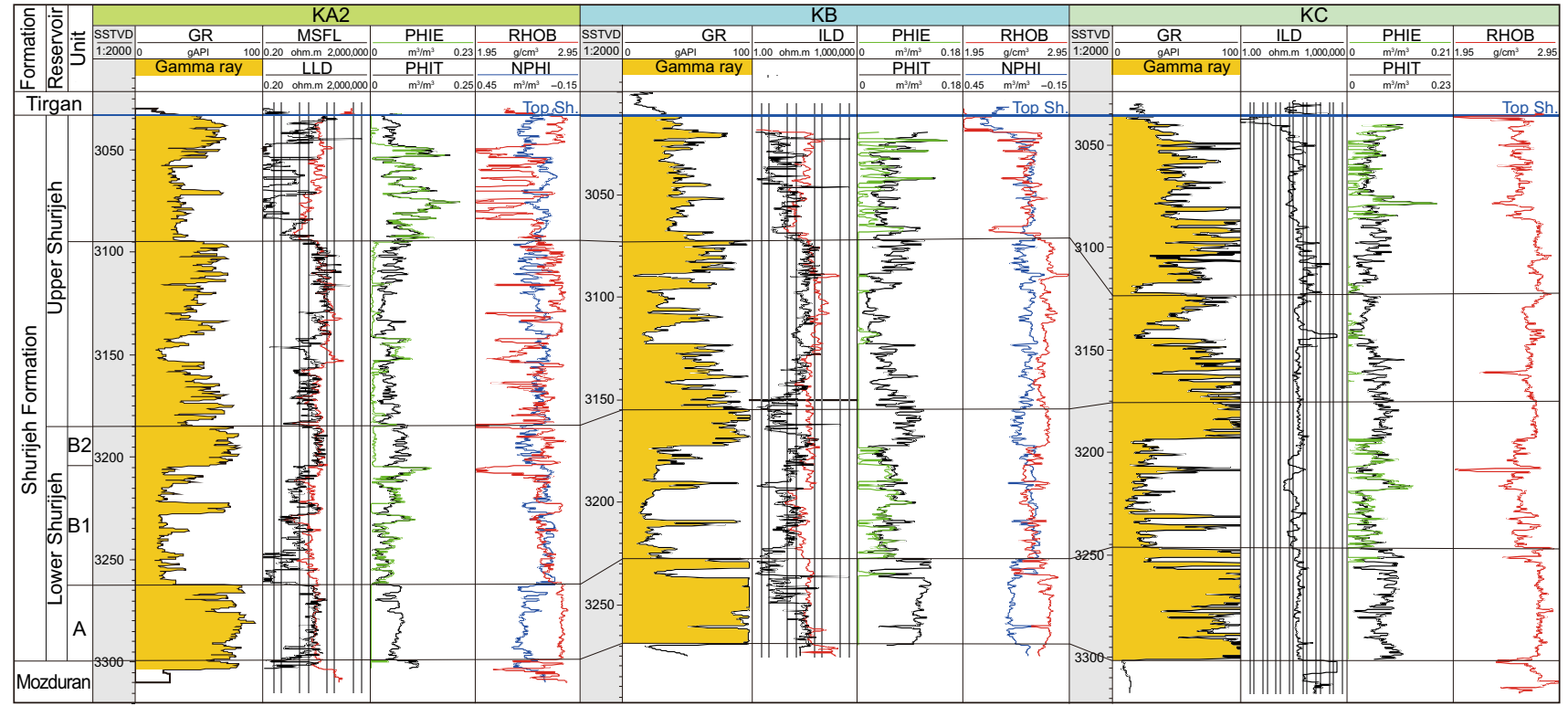

Fig. 5 Stratigraphic cross section based on well logs. a Correlation showing the units $\mathrm{A}, \mathrm{B}_{2}$ and $\mathrm{C}$ have relatively high gamma ray and resistivity values. Density and neutron $\log$ curves are separated in units $\mathrm{A}, \mathrm{B}_{2}$ and $\mathrm{C}$ that are indicate fine-grained facies. High resistivity values in sandstone layers of unit $B_{1}$ in well KL2 and unit D in well KA2 show the presence of hydrocarbon. $\mathbf{b}$ Well log correlation in the wells located in the delta indicates sandstone layers of unit $\mathrm{D}$ with high effective porosity formed a good prospective zone for hydrocarbon. See wells location in Fig. 1

lithofacies to be identified. Impedance contrasts between the underlying Jurassic carbonates of the Mozduran Formation and the overlying shale of the Shurijeh Formation led to a strong reflector in seismic data. Sandstone intervals overlying the low impedance shale resulted positive/ negative reflection coefficients.
Figure 7 shows energy, entropy and heterogeneity texture attribute slices of horizons $A, B_{1}$ and $B_{2}$. The main channel belt is extracted from the central part of the horizons Slices $A$ and $B_{1}$, highlighted with relatively high values of energy and homogeneity and low entropy contents (Fig. 7). This area shows high frequency in spectral decomposition (Fig. 8) 


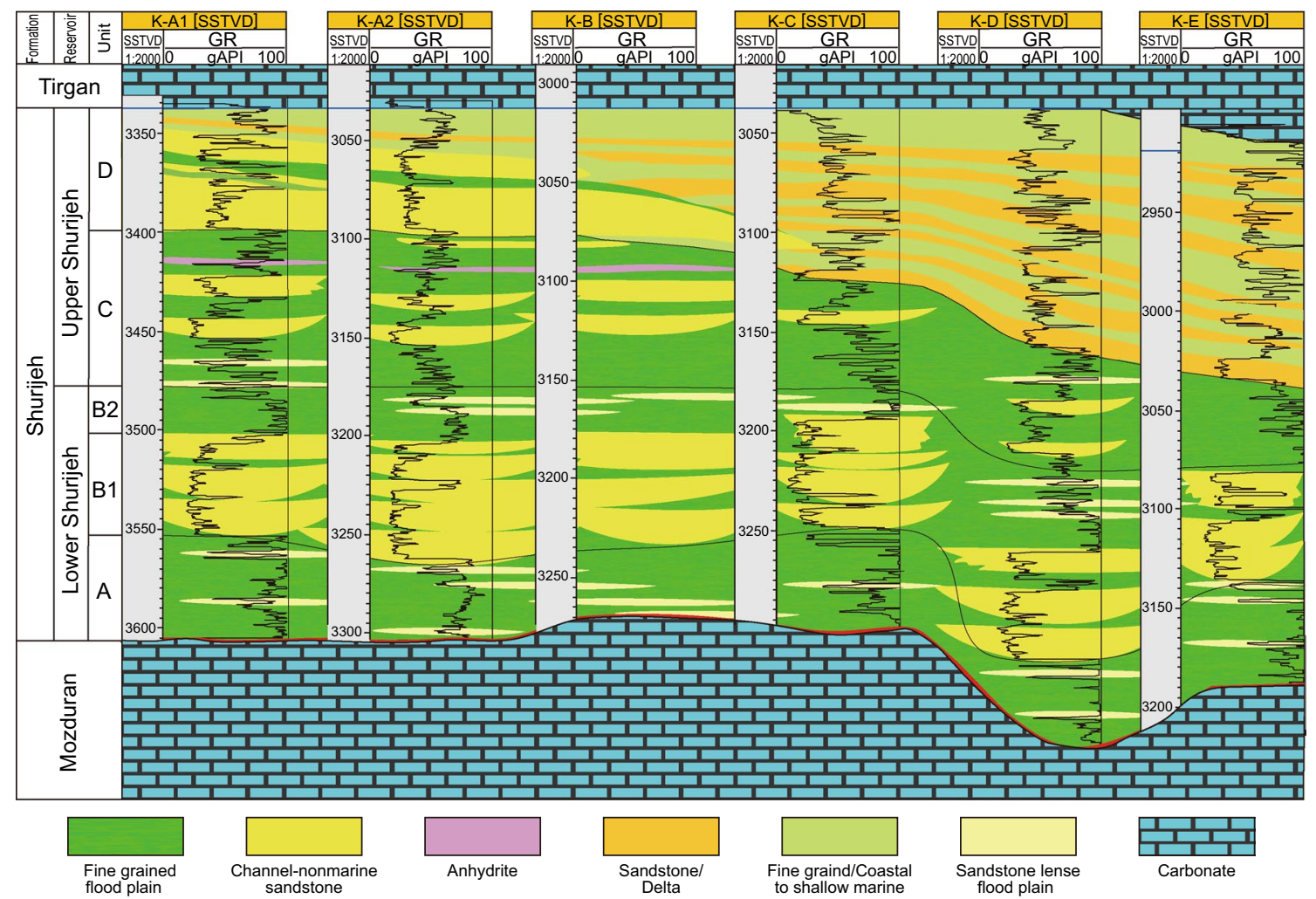

Fig. 6 Stratigraphic cross section based on the gamma-ray logs showing the distribution of flood plain, blocky channel and sandstone lenses patterns in the lower Shurijeh and non-marine to delta and shallow marine environment in the upper Shurijeh Formation (modified after Hosseinyar et al. 2018). See wells location in Fig. 1

and low values in coherency attribute maps (Fig. 10), which is related to discontinuous or irregular geological features such as the edges of a carved valley (Chopra and Marfurt 2007; Infante-Paez et al. 2017). The main channel belt was recorded with discontinuous reflections on the seismic section (Fig. 9a) and had flowed in a northeast direction (Figs. 7, 8 and 10) which turned downstream to the northnorthwest with a divergent pattern. Areas between the channels were low energy and homogeneity values with moderate entropy (Fig. 7) and low frequency in spectral decomposition attributes (Fig. 8) that can be related to the flood plain and overbank environments. Seismic attribute anomalies on the east corner of the attribute maps include some east to west channel shape features in Horizon Slice $B_{1}$ (Figs. 7 and 8).

Analysis of the attribute anomalies reveals channel features in the west side of the map (nominated Ch1) which had moderate-to-high energy with low entropy values on horizon Slice A and a moderate value of entropy on horizon Slice $B_{1}$ (Figs. 7 and 9c). This channel $8.5 \mathrm{~km}$ in length was revealed in spectral decomposition at $30 \mathrm{~Hz}$ frequency, but was poorly defined in low-frequency spectral decomposition attributes (Fig. 8). The narrow channel $\mathrm{Ch} 2$ (to the right of Ch1) $11 \mathrm{~km}$ in length is revealed in the spectral decomposition map at $30 \mathrm{~Hz}$ in horizons $\mathrm{A}$ and $\mathrm{B}_{1}$ (Fig. 8) and coherency attribute on horizon $\mathrm{B}_{1}$ (Fig. 10b, e), which had flowed to the east, the same as Ch1. Channels Ch1 and $\mathrm{Ch} 2$ are not revealed on seismic attribute maps of horizon $\mathrm{B}_{2}$ and analyses of these maps and seismic sections show channels $\mathrm{Ch} 1$ and $\mathrm{Ch} 2$ were filled before deposition of horizon $\mathrm{B}_{2}$ (Figs. 7, 8, 9 and 10).

Two other features of horizonsslices $\mathrm{A}$ and $\mathrm{B}_{1}$ are extracted from seismic attributes, which are highlighted by the dashed polygons in Figs. 7, 8 and 10. Feature G1 has maximum length and width at about 2000 and $1300 \mathrm{~m}$, respectively. This feature is interpreted as a confluence area where channels $\mathrm{Ch} 1, \mathrm{Ch} 2$ and $\mathrm{Ch} 3$ are connecting with each other. The confluence area (feature G1) filled during sedimentation of horizons $A$ and $\mathrm{B}_{1}$, as attribute maps of the horizon $\mathrm{B}_{2}$ do not show this feature (Figs. 7, 8, 9 and 10). Feature $\mathrm{G} 2$ is about 3500 by $1500 \mathrm{~m}$ in size which is seen in all seismic attributes on horizon A (Figs. 7, 8a, d and 10a, d). Correlation with seismic sections (Fig. 9a) shows that feature $\mathrm{G} 2$ is related to channel incision at the base of the Formation.

Forms and locations of the extracted channels change from horizon Slice A to horizon Slice $\mathrm{B}_{2}$ and channels migrated to the east-southeast. Moreover, channels Ch1, 
(a)

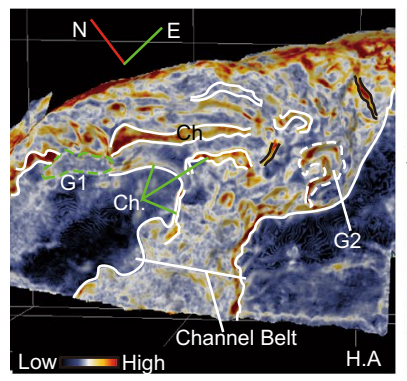

(b)

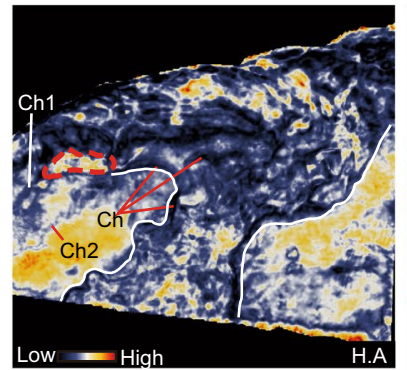

(c)

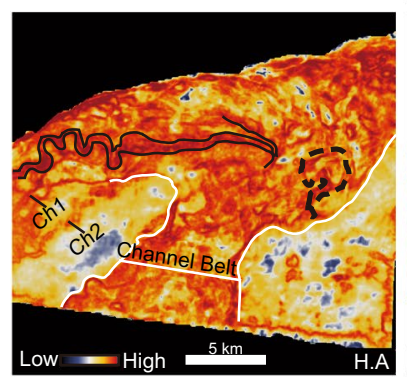

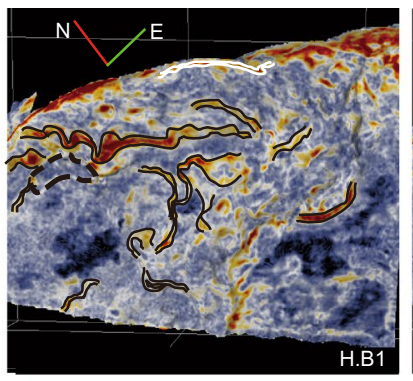
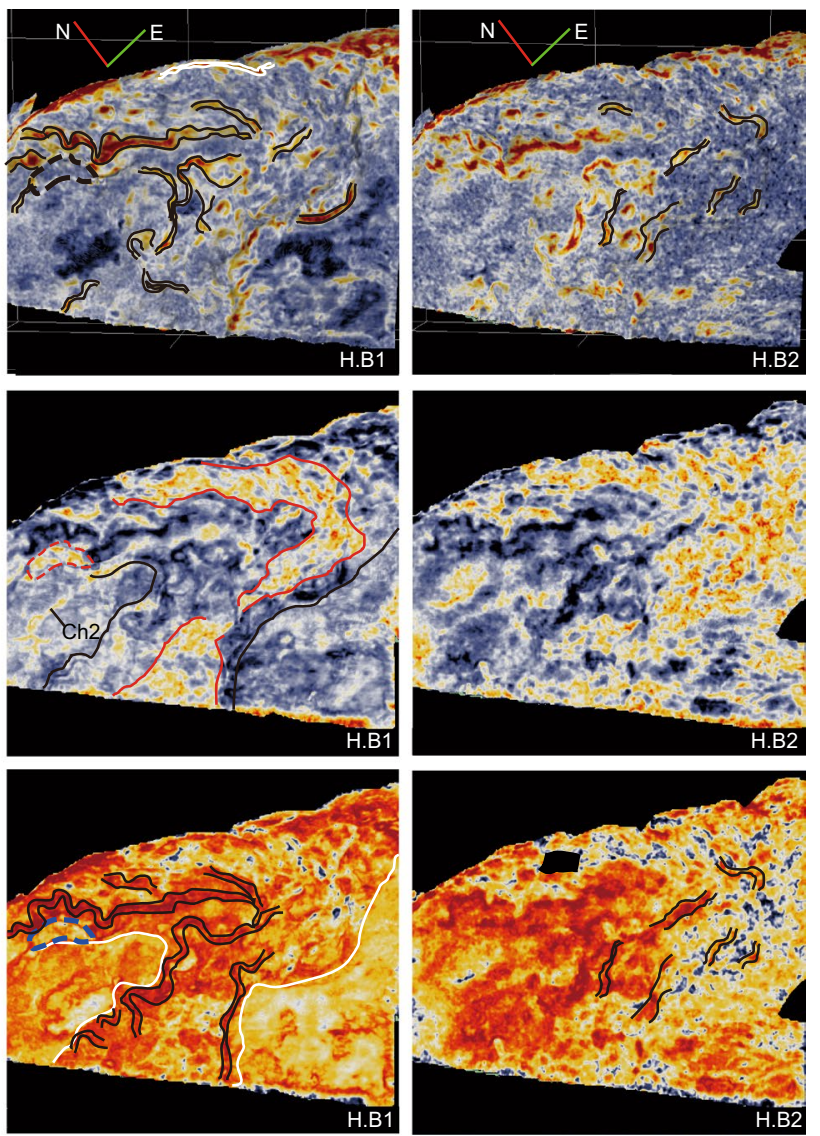

Fig. 7 Texture attribute horizon slices; a homogeneity, which the channel belt is detectable in the center of the seismic volume by moderate to high values. Homogeneity is very low in horizon $\mathrm{B}_{2}$; $\mathbf{b}$ entropy, the main valley showing low entropy values. The maximum values of entropy are seen on horizon $\mathrm{B}_{2}$; $\mathbf{c}$ energy the channel belt with high energy values is obvious. Channel direction could be detected by high energy and high homogeneity area that are associated with low entropy values in all horizon slices. The channel confluence area $(G 1)$ and incised channel area $(G 2)$ highlighted are revealed on the maps. Ch: channel. See location in Fig. 1

$\mathrm{Ch} 2, \mathrm{Ch} 3$ and $\mathrm{Ch} 4$ do not show on horizon Slice $\mathrm{B}_{2}$ (Figs. 8 and 10). In addition, an abandoned channel is present in horizon Slice $\mathrm{B}_{2}$ (Fig. 10c, f). As shown in Fig. 10c, f, channels $\mathrm{Ch} 3$ and $\mathrm{Ch} 4$ are in yellow (ghost channels), while channel $\mathrm{Ch} 5$ and its tributaries in the northern parts of the study area are shown in blue. This indicates that the main river flow (in horizon Slice $\mathrm{B}_{2}$ ) was limited to the channel Ch5 in the eastern area (Fig. 8). Moreover, other fluvial features such as tributary channels and point bars are detected on the maps (Fig. 10c, f).

Generally, sinuosity of channels increases from horizon A to horizon $\mathrm{B}_{2}$ (Figs. 7, 8 and 10). The seismic data analyses reveal that mean sinuosity of the channels in horizon $\mathrm{A}$ is 1.18 to 1.3 , in horizon $\mathrm{B}_{1}$ about 1.5 and in horizon $\mathrm{B}_{2}$ is about 1.9-2.0.

As seen in Fig. 11, horizon $\mathrm{C}_{1}$ (beginning of the upper Shurijeh) is limited to the Khangiran area and pinches out to the east (Gonbadli Field and Badkhyiz-Maimana Uplift). Vertical seismic sections show discontinuous reflections in horizon $C_{1}$ as well (Fig. 9). Seismic attributes reveal the channels in horizon $\mathrm{C}_{1}$ flowed from $\mathrm{S}-\mathrm{N}$ direction (Figs. 11a, b). Gradually, sediments were more extended to the east and the flow direction changes to the northeast, during deposition of horizons $\mathrm{C}_{2}$ and $\mathrm{C}_{3}$ (Fig. 11c, d). The amplitude of existing channels on spectral decomposition maps on $\mathrm{C}_{2}$ and $\mathrm{C}_{3}$ (Fig. 11c, d) decreased downstream, while channel widths increased. Some local features present with high amplitude in the strike of channels are related to channel bend sediments.

Two delta features extracted from the seismic are the main geological features in the upper horizon (horizon D) of the Shurijeh Formation. These northeast oriented deltas and connected channels are extracted on spectral decomposition and instantaneous attributes (Fig. 11e, h). Vertical seismic sections (Fig. 12) and stratigraphic well-log correlation (Fig. 6) confirm the presence of these deltas. The stratigraphic cross section along the axis of the delta shows the presence of sandstone layers related to the delta in boreholes (Fig. 6). Seismic attribute maps indicate that both deltas migrate during deposition. This can also be seen 

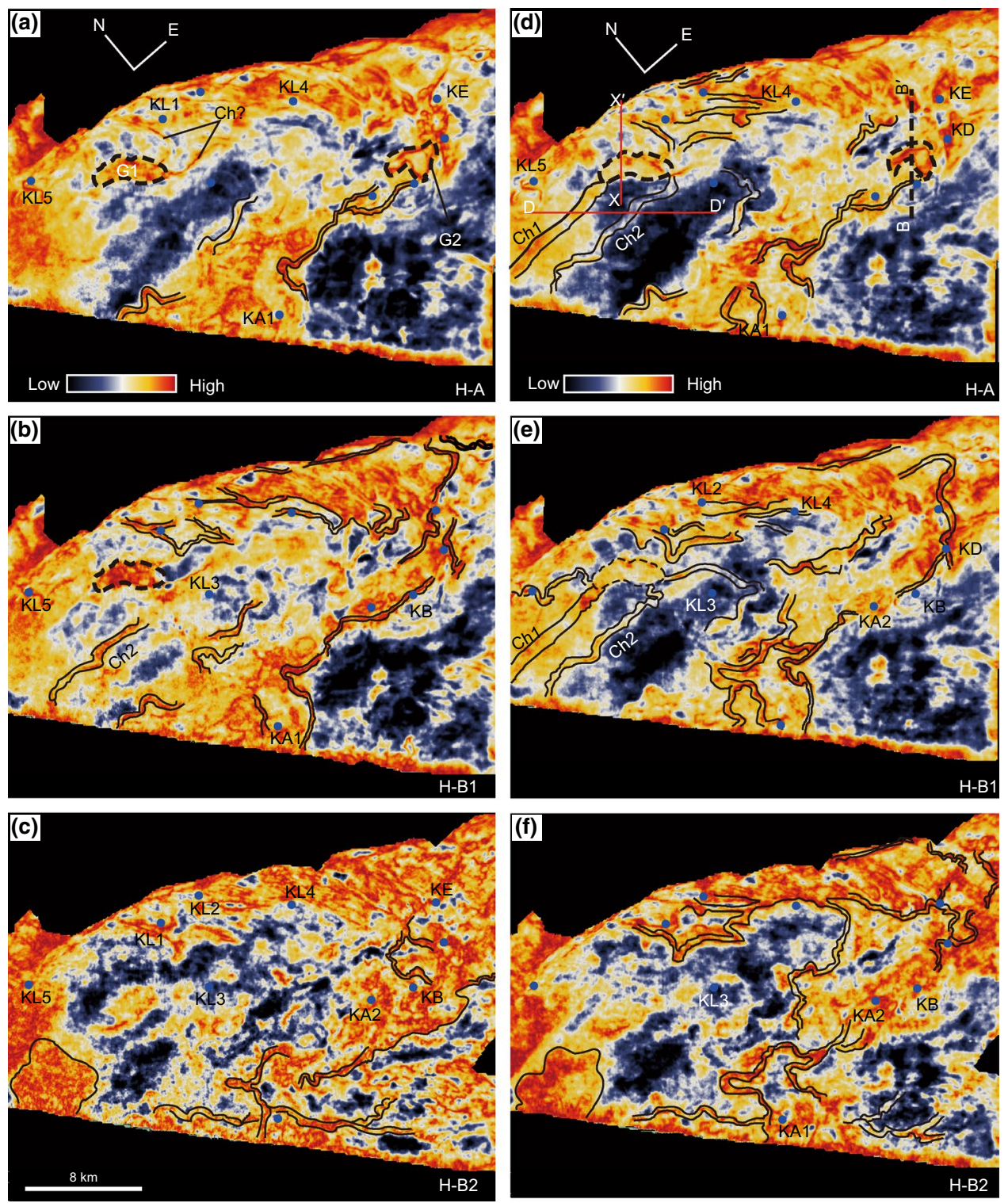

Fig. 8 Horizontal slice spectral decomposition at $5 \mathrm{~Hz}$ (a) and $30 \mathrm{~Hz}$ (b) through the seismic-amplitude volume showing the channels axis and sinuosity. Channels are more visible at $10 \mathrm{~Hz}$ frequency in horizons $\mathrm{A}(H-\mathrm{A})$ and $\mathrm{B}\left(H-\mathrm{B}_{1}\right)$ while in horizon $\mathrm{B}_{2}(H-\mathrm{B} 2)$ channels revealed at $5 \mathrm{~Hz}$

on color blending spectral decomposition attributes as well (Fig. 11h).

\section{Discussion}

As stated earlier, the Shurijeh succession formed two distinct reservoirs in the Khangiran Field. All wells were drilled based on structural traps and several dry wells had been drilled in the Shurijeh target. Analyses of sedimentary facies, seismic and borehole data indicate lithology and sedimentary elements vary throughout the field. In addition, the depositional systems of the lower and upper Shurijeh are different. Moreover, producing wells from Lower and Upper Shurijeh reservoirs are located in different areas.

Our results indicate a braided channel system for the lower part of the Shurijeh Formation along the outcrop belt (Moussavi-Harami and Brenner 1990, 1992; Hosseinyar et al. 2018) and in the Khangiran Field. Generally, three different channel types are detected in the Lower Shurijeh Formation in the Khangiran Field, including:

Type I channels, on horizon A, display a low sinuosity (1.18-1.3) with relatively short meander-belts. As seen on the gamma ray and resistivity logs, their values on the channel belt and overbank area (on attribute maps) are high (Fig. 5), indicating fine-grained claystone, siltstone and 

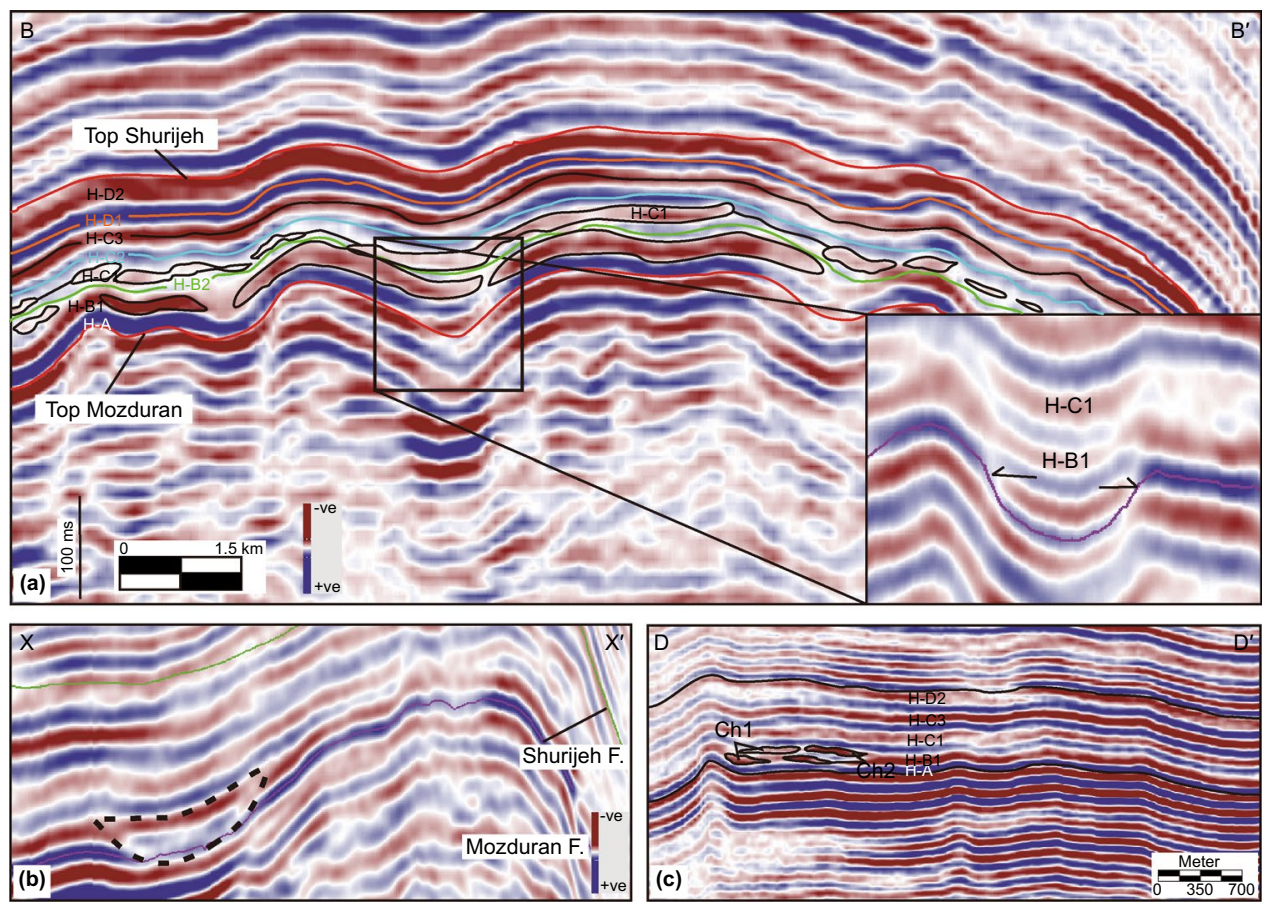

Fig. 9 a Inline seismic section, discontinuous reflectors on horizons A to $\mathrm{C} 1$ indicate the presence of the fluvial channeling system. Incised channel fill (inclined termination) as feature G2 is recorded in the seismic data; b Feature G1 extracted in seismic section; c channels Ch1 and $\mathrm{Ch} 2$ revealed in seismic section and are covered with horizon $\mathrm{B}_{2}$. See locations in Fig. 8d

evaporite with sandstone intervals lithofacies in the horizon (unit) A as well as the channel confluence area ( $G 1$ in Fig. 7). Generally, analyses of channel sinuosity and boreholes data demonstrate dominantly bypassed depositional conditions based on Posamentier (2001), Wood (2007) and Karamitopoulos et al. (2014). Before and during deposition of horizon $\mathrm{A}$, in which channels incised into the lower carbonate sediments (Mozduran Formation), fine-grained facies have been deposited during marine regressions in flood plains and overbank areas. The same condition reported from other parts of the basin in Turkmenistan and North Afghanistan where channels eroded the Gaurdak and Upper Jurassic carbonate layers (Brookfield and Hashmat 2001; Ulmishek 2004; Klett et al. 2006). Petrophysical analyses show that fine-grained facies in the unit A have high values of resistivity and the neutron and density log curves are separated from each other in all wells (Fig. 5); so that the total porosity is relatively good but the effective porosity is near zero.

Type II, in horizon $\mathrm{B}_{1}$, channel sinuosity changes from 1.3 to about 1.5 and seismic attributes show the creation of point bars (Fig. 10). The log motifs and low resistivity values at the base of unit B in most wells are confirmed in conjunction with core and cutting data (sandstones, micro-conglomerates and siltstones). As well channel sinuosity confirms bed load deposition in the multi-channel braided fluvial systems. To the top of this unit, in some wells, resistivity increases and deep resistivity is differentiated from MSFL (Micro-Spherical Focused Log). In addition, the density $\log$ curve moved to the left side of the neutron log (Fig. 5). Therefore, effective porosity is close to the total porosity in sandstone lenses in this unit. This is related to the presence of hydrocarbon (gas) which is assigned to downstream E-W trending channel sediments.

Based on seismic attribute maps, outcrop and subsurface stratigraphic data, a marine environment was established in the northwest of the Khangiran and west-southwest of the Murgab Depression (on the Kopeh Dagh Foredeep), during deposition of the lower Shurijeh Formation. Therefore, fluvial sand sized sediments deposited in downstream areas close to the marine environment are high potential reservoir layers in the Khangiran Field.

Type III, in horizon $\mathrm{B}_{2}$, includes channels with higher sinuosity and coastal plain features such as distributary and oxbow channels (Fig. 10). The horizon slice $\mathrm{B}_{2}$ shows the final stage of channel filling as the size and number of the channels reduced compared to $\mathrm{B}_{1}$ and $\mathrm{A}$. In addition, the coastal plain has migrated toward the east as sea/base level rises, covering the underlying channels (Figs. 7 and 10). Channel system sinuosity increased in this horizon and ranges from 1.9 to 2.0. Borehole data and stratigraphic correlation indicate expansion of coastal and flood plain conditions and deposition of fine-grained sediments in this area (wells KL3 and KL5). Sandy-grained sediments were 

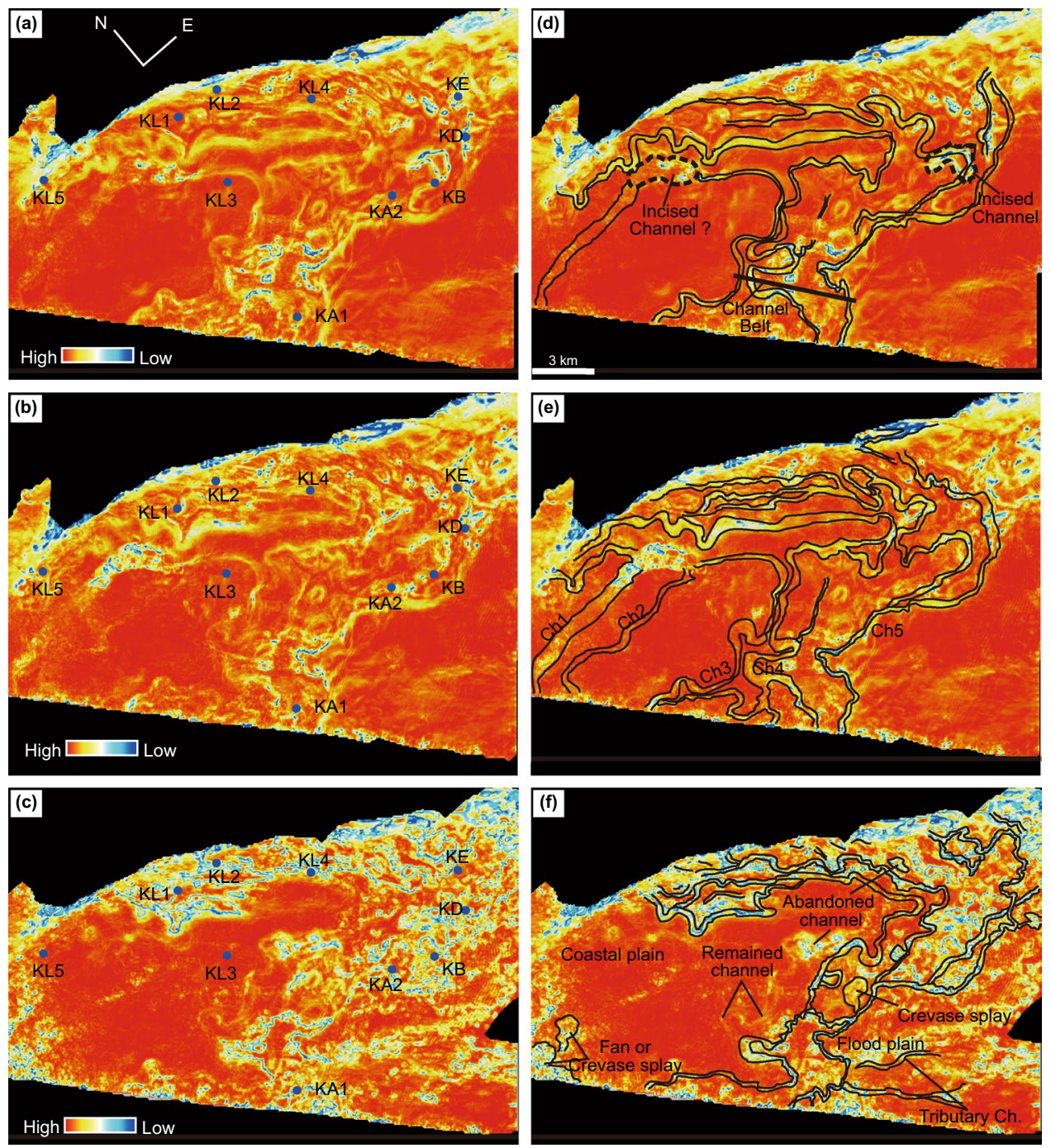

Fig. 10 Un-interpreted and interpreted coherence attribute at horizon slices are showing characterization of depositional features and multichannel fluvial system. Channel sinuosity increased from horizon $\mathrm{A}$ to $\mathrm{B}_{2}$ and point bars developed. Channels Ch1 and Ch2 covered horizon $\mathrm{B}_{2}$ and the main flow migrated to the east. Fluvial features such as creeks, crevasse splays and tributary channels were more distributed in horizon $\mathrm{B}_{2}$. Arrows show the ghost channels in the horizon $\mathrm{B}_{2}$. Ch: channel. See location in Fig. 1

deposited in the channels that flowed toward the east and north sides of the field during this time (e.g. well KA2 in Fig. 5, 8 and 10); where the fine-grained facies are very thin (Fig. 5).

Relative sea/base level fall during deposition of the middle Shurijeh (unit C) has led to erosion and reworking of deposited sediments on the upstream area and surrounding palaeo-highs (Hosseinyar et al. 2018). Deposition of upper Shurijeh Formation was affected by relative sea/ base level rise, based on seismic attribute maps and retrogradational pattern of facies in stratigraphic correlation section (Figs. 6 and 11), where the coast line retrograded to the south in the east Kopeh Dagh Foldbelt and also to the east and north of KDADB (Hosseinyar et al. 2018). The widespread flood plain environment dominated during deposition of the horizons $\mathrm{C}_{1}$ and $\mathrm{C}_{2}$ (unit $\mathrm{C}$ in well $\operatorname{logs}$ ) in the Khangiran field which is recorded on the gamma-ray content in well logs (Fig. 6) and seen in the cuttings. Based on attribute maps (Fig. 11), rivers flowed into the Khangiran Field at that time. It is recorded in borehole data, too (in wells KA1, KA2 and KB in Figs. 5 and 6). In addition, although gamma ray and resistivity values are relatively high in unit $\mathrm{C}$, but density and neutron $\log$ curves do not differentiate more (Figs. 5 and 6). Fine-grained sediments (shale, mudstone) and evaporites (anhydrite) are mostly deposited in the flood plain. Channels on horizon slices $\mathrm{C}_{2}$ and $\mathrm{C}_{3}$ are revealed with low amplitude on attribute maps (Fig. 11). This indicates channels with a fine-grained bed load (Ahmad and Rowell 2012). Therefore, fine-grained 

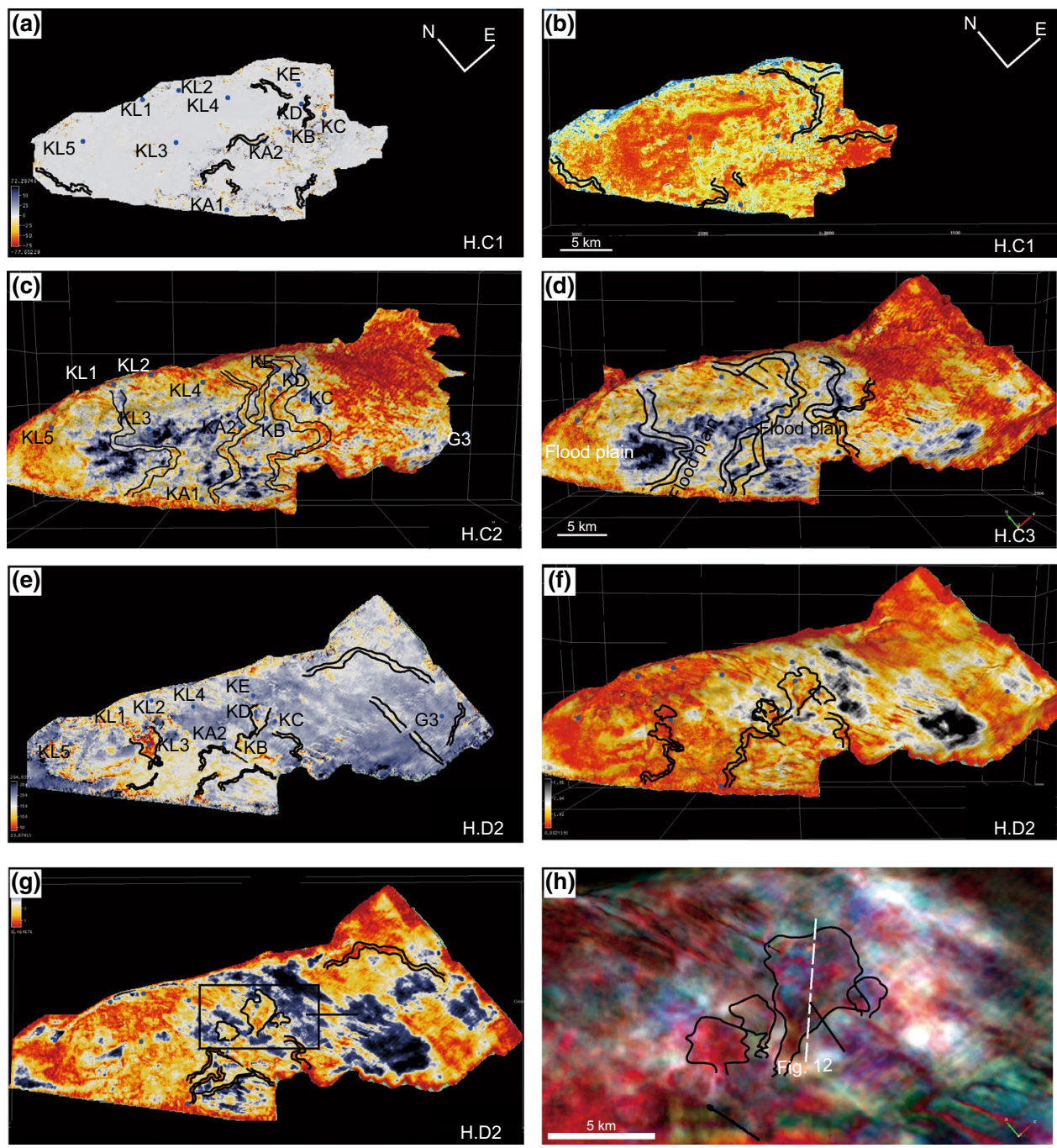

Fig. 11 Different seismic attributes in the Upper Shurijeh Formation. a thin layer indicator instantaneous and $\mathbf{b}$ coherency maps revealing the channels on horizon $\mathrm{C}$, where their flow directions are different form lower horizons $\left(\mathrm{A}\right.$ to $\left.\mathrm{B}_{2}\right)$; $\mathbf{c}$ and $\mathbf{d}$ spectral decomposition horizon slices on horizons $\mathrm{C}_{2}$ and $\mathrm{C}_{3}$, respectively. Deposition of sediments more expanded to the east and channels oriented northeastward; e Spectral decomposition at $10 \mathrm{~Hz}, \mathbf{f}$ amplitude instantaneous and $\mathbf{g}$ texture attributes on horizon $\mathrm{D}_{2}$ showing Formation of two deltas in the Upper Shurijeh Formation; $\mathbf{h}$ color blending spectral decomposition at 5,14 and $30 \mathrm{~Hz}$ showing the delta migration; map area is drawn in $11 \mathbf{g}$ Dotted line: location of the seismic section in Fig. 12

sandstone and siltstone are deposited in channels which could not form a reservoir zone.

The identified deltas in the Khangiran area were formed during sea level rise. As shown on the attribute maps, the western delta is a small delta and did not expand more (Fig. 11). In addition, well log analyses indicate that the density log curve located on the right side of the neutron $\log$ and resistivity of the sandstone layers is low (well KL2 in Fig. 5). Therefore, it could not form a reservoir zone in the field. The eastern delta is distributed over a large area and thick sandstone facies had aggraded through time. Petrophysical investigation indicate a permeable sandstone zone where the density log curve located on the left side of the neutron log and resistivity logs separated from each other (Fig. 5). All producing wells from Upper Shurijeh are limited to this high effective-porosity deltaic sandstone. The sandstone lenses are thin and do not form reservoirs in the rest of the Khangiran Field (Figs. 5 and 6).

Moreover, in the Murgab Depression, the Hauterivian Sandstone Bed deposited in a delta setting, which its isopach maps and stratigraphical equivalents in Turkmenistan (Fig. 13 in Ulmishek 2004) show that this formation thins toward the basin margin (from 120 to $130 \mathrm{~m}$ in the central basin to 10-20 $\mathrm{m}$ in the margin), toward the Khangiran and Gonbadli fields. It seems that the Formation of these deltas took place at the same time according to the relative sea level rise (Hosseinyar et al. 2018). 


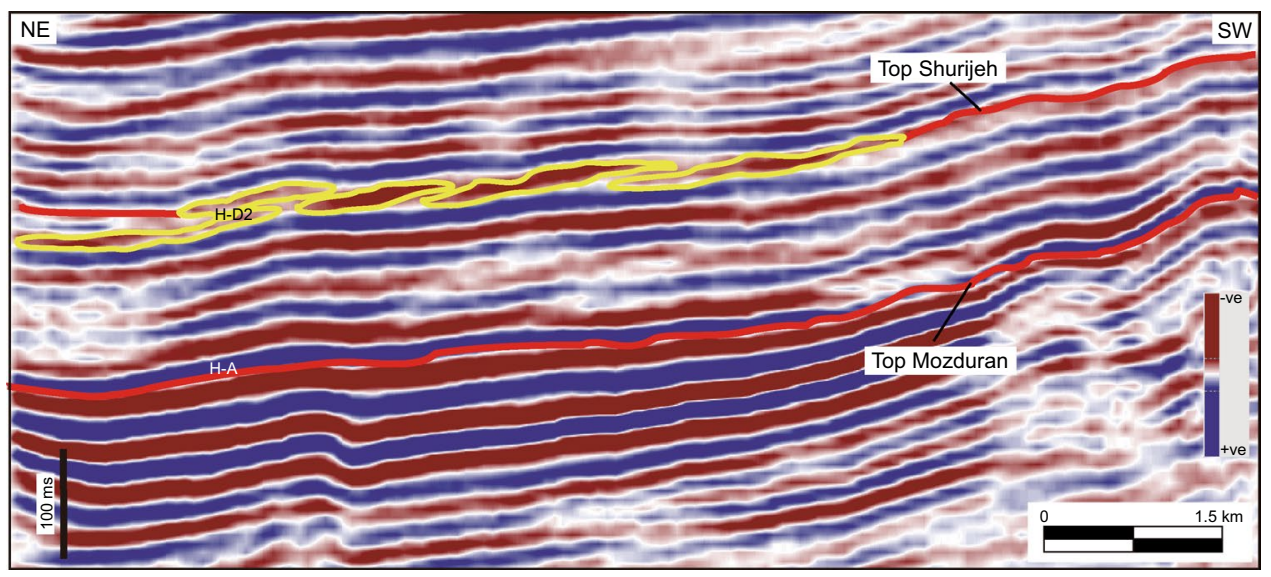

Fig. 12 Seismic section showing the prograding pattern (yellow lines) on horizon $\mathrm{D}_{2}$, which indicates distribution of deltas in the basin. See location in Fig. 11h

\section{Conclusions}

Seismic geomorphological analyses indicate that the palaeo-flow direction in the Khangiran Field was from the south-southwest toward the northeast, where it turned to the north-northwest downstream. This kind of directional change might be explained by buried east-west trending deep-seated faults.

Early Cretaceous marine regression as well as erosional/ bypassing conditions led to distribution of a multi-channel fluvial system in the KDADB. Then, non-marine (dominantly fluvial) facies deposited in the Afghan-Tajik to the Khangiran area, which gradually changed to coastal and shallow marine sediments to the west. As a result, the fluvial channel-fill sandstones formed a unique reservoir zone in downstream parts of the rivers in the Khangiran Field. Therefore, the lower Shurijeh Formation has potential for reservoirs, depending upon the distribution of channels as well as the reservoir quality of the channel-fill deposits.

This study also showed that the main Lower Cretaceous reservoirs of the KDADB are formed in deltaic systems (e.g. Khangiran and Dauletabad fields) which are related to depositional conditions and paleogeography of the basin.

Our conclusion emphasizes the stratigraphic aspect of the Shurijeh-Shatlyk reservoirs in the eastern Kopeh Dagh Foldbelt where the reservoir potential also improved during folding. In addition, distribution of producing wells on the Khangiran and Dauletabad fields supports stratigraphic elements of the traps. Therefore, the possible delta and barrier island deposits (far from the evaporite of the Gaurdak Formation) and also fluvial channels (as a second prospect) of the Shurijeh-Shatlyk succession can be the best prospective areas for future exploration in the KDADB.
Acknowledgements The authors thank the NIOC Exploration Directorate for supporting the project, data preparation and permission to publish. We also thank to the Ferdowsi University of Mashhad for supporting this project (Research Project Code: 3/27868).

Open Access This article is distributed under the terms of the Creative Commons Attribution 4.0 International License (http://creativeco mmons.org/licenses/by/4.0/), which permits unrestricted use, distribution, and reproduction in any medium, provided you give appropriate credit to the original author(s) and the source, provide a link to the Creative Commons license, and indicate if changes were made.

\section{References}

Afshar-Harb A. Geological quadrangle map of Sarakhs, 1:250,000 scale (one sheet). Tehran: Exploration and Production, NIOC; 1982.

Afshar-Harb A. The stratigraphy, tectonics and petroleum geology of the Kopet Dagh region, northern Iran. Imperial College of Science and Technology, University of London, 1979 (Ph.D. thesis).

Aghaei A, Zand-Moghadam H, Moussavi-Harami R, Mahboubi A. Sequence stratigraphic analysis and sea-level history of the upper jurassic deposits (Mozduran Formation), south of Aghdarband, NE Iran. Hist Biol. 2018. https://doi.org/10.1080/08912 963.2017 .1421184 (in press).

Ahmad MN, Rowell P. Application of spectral decomposition and seismic attributes to understand the structure and distribution of sand reservoirs within Tertiary rift basins of the Gulf of Thailand. Lead Edge 2012;31(6):630-34

Alavi M, Vaziri H, Seyed-Emami K, Lasemi Y. The Triassic and associated rocks of the Aghdarband areas in central and northeastern Iran as remnant of the southern Turanian active continental margin. GSA Bull. 1997;109:1563-75.

Berberian M, King GCP. Toward a paleogeography, tectonic evolution of Iran. Can J Earth Sci. 1981;18:210-65.

Bridge JS, Alexander J, Collier REL, Gawthorpe RL, Jarvis J. Ground-penetrating radar and coring used to document the largescale structure of point-bar deposits in 3-D. Sedimentology. 1995;42:839-52. 
Brookfield ME, Hashmat A. The geology and petroleum potential of the North Afghan platform and adjacent areas (northern Afghanistan, with parts of southern Turkmenistan, Uzbekistan, and Tajikistan). Earth Sci Rev. 2001;55(1):41-71.

Brown AR (2011) Interpretation of three-dimensional seismic data, 7th Edition. AAPG Memoir 42: 646.

Brunet M-F, Ershov AV, Korotaev MV, Melikhov VN, Barrier E, Mordvintsev DO, et al. Late Palaeozoic and Mesozoic evolution of the Amu Darya Basin (Turkmenistan, Uzbekistan). In: Brunet M-F, McCann T, Sobel ER editors. Geol evolution of Central Asian Basins and the Western Tien Shan Range. Geol Soc Lond Spec Publ; 2017. 427.

Cant DJ, Walker RG. Fluvial processes and facies sequences in the sandy braided South Saskatchewan River, Canada. Sedimentology. 1978;25:625-48.

Carter DC. 3-D seismic geomorphology: insights into fluvial reservoir deposition and performance Widuri field, Java Sea. AAPG Bull. 2003;87:909-34.

Chinwuko AI, Onwuemesi AG, Anakwuba EK, Onyekwelu CU, Okeke HC, Obiadi II. Coblending of seismic attributes for interpretation of channel geometries in Rence Field of Niger Delta, Nigeria. Interpretation. 2015;3(4):83-95. https://doi. org/10.1190/INT-2014-0083.1.

Chopra S, Marfurt KJ. Seismic attributes for prospect identification and reservoir characterization. Tulsa: SEG Geophysical developments; 2007. p. 464.

Davies RJ, Posamentier HW, Wood LJ, Cartwright JA. Seismic geomorphology: Applications to hydrocarbon exploration and production. Geol Soc Lond Spec Publ. 2007; 274-277.

Eichkitz CG, Schreilechner MG, Groot PD, Amtmann J. Mapping directional variations in seismic character using graylevel co-occurrence matrix-based attributes. Interpretation. 2015;3(1):13-23. https://doi.org/10.1190/INT-2014-0099.1.

Garzanti E, Gaetani M. Unroofing history of late Palaeozoic magmatic arcs within the Turan Plate (Tuarkyr, Turkmenistani). Sediment Geol. 2002;151:67-87.

Golonka J. Plate tectonic evolution of the southern margin of Eurasia in the Mesozoic and Cenozoic. Tectonophysics. 2004;381(14):235-73. https://doi.org/10.1016/j.tecto.2002.06.004.

Hosseinyar G, Moussavi-Harami R, Abdollahie Fard A, Mahboubi A, Noemani Rad R, Ebrahimi MH. Facies analyses and depositional setting of the Lower Cretaceous Shurijeh-Shatlyk Formations in the Kopeh Dagh-Amu Darya Basin. Geol J. 2019;54(3):1715-1729. https://doi.org/10.1002/gj.3264

Infante-Paez L, Cardona LF, McCullough B, Slatt R. Seismic analysis of paleotopography and stratigraphic controls on total organic carbon: rich sweet spot distribution in the Woodford Shale, Oklahoma, USA. Interpretation. 2017;5(1):T33-47.

Jolivet M Mesozoic tectonic and topographic evolution of Central Asia and Tibet: a preliminary synthesis. In: Brunet M-F, McCann T, Sobel ER (eds) Geological evolution of Central Asian Basins and the Western Tien Shan Range. Geol Soc Lond Spec Publ; 2015. 427.

Karamitopoulos P, Weltje GJ, Dalman RAF. Allogenic controls on autogenic variability in fluvio-deltaic systems: inferences from analysis of synthetic stratigraphy. Basin Res. 2014;26:767-79.

Kalantari A. Biofacies relationship of the Kopet-Dagh region. Tehran: NIOC, Exploration and Production; 1987.

Kavoosi MA. Inorganic control on original carbonate mineralogy and creation of gas reservoir of the Upper Jurassic carbonates in the Kopet-Dagh Basin, NE, Iran. Carbonates Evaporites. 2014;29:419-32.

Kavoosi MA, Lasemi Y, Sherkati S, Moussavi-Harami R. Facies analysis and depositional sequences of the Upper Jurassic Mozduran Formation, a reservoir in the Kopet-Dagh Basin,
NE Iran. J Pet Geol. 2009;32(3):235-60. https://doi.org/10.111 $1 / \mathrm{j} .1747-5457.2009 .00446 . x$.

Khalifeh MA, Cantuneanu O. Sedimentology of the fluvial and fluvio-marine facies of the Bahariya Formation (Early Cenomanian), Bahariya Oasis, Western Desert, Egypt. J Afr Earth Sci. 2008;51(2):89-103.

Klett TR, Ulmishek GF, Wandrey CJ, Agena WF, U.S. Geological Survey-Afghanistan Ministry of Mines and Industry Joint Oil and Gas Resource Assessment Team. Assessment of undiscovered technically recoverable conventional petroleum resources of Northern Afghanistan. United States Geological Survey Open-File Report 1253; 2006.

Koykka J. Precambrian alluvial fan and braid plain sedimentation patterns: example from the Mesoproterozoic Rjukan Rift Basin, Southern Norway. Sediment Geol. 2011;234(1):89-108.

Kryuchkov VE. Lithologic features of sediments of the Shatlyk Horizon of the Malay-Chartak Zone of highs in connection with gas prospects of East Turkmenistan. Geologiya Nefti i Gaza. 1996;5:4-10 (in Russian) (English Abstract in Petroleum Geology, 31, 165-171 (1997)).

Miall AD. Architectural element analysis: a new method of facies analysis applied to fluvial deposits. Earth Sci Rev. 1985;22:261-308.

Miall AD. Reconstructing the architecture and sequence stratigraphy of the preserved fluvial record as a tool for reservoir development: a reality check. AAPG Bull. 2006;90(7):989-1002.

Miall AD. Fluvial depositional systems. Berlin: Springer; 2014. p. 319.

Mortazavi M, Moussavi-Harami R, Mahboubi A. Detrital mode and geochemistry of the Shurijeh Formation (Late Jurassic-Early Cretaceous) in the central and western parts of the intracontinental Kopet-Dagh Basin, NE Iran: implications for provenance, tectonic setting and weathering processes. Acta Geol Sin. 2013a;89(4):1058-80.

Mortazavi M, Moussavi-Harami R, Brenner R, Mahboubi A. Stable isotope record in pedogenic carbonates in northeast Iran: implications for Early Cretaceous (Berriasian-Barremian) paleovegetation and paleoatmospheric $\mathrm{P}(\mathrm{CO} 2)$ levels. Geoderma. 2013b;211212:85-97. https://doi.org/10.1016/j.geoderma.2013.07.008.

Moussavi-Harami R, Brenner RL. Lower Cretaceous (Neocomian) fluvial deposits in eastern Kopet-Dagh Basin, northeastern Iran. Cretac Res. 1990;11:163-74. https://doi.org/10.1016/S0195 -6671(05)80031-X.

Moussavi-Harami R, Brenner RL. Geohistory analysis, petroleum reservoir characteristics of Lower Cretaceous (Neocomian) sandstones, eastern Kopet-Dagh Basin, North Eastern Iran. AAPG Bull. 1992;76:1200-8.

Moussavi-Harami R, Brenner RL. Diagenesis of non-marine petroleum reservoirs: the Neocomian (Lower Cretaceous) shurijeh Formation, Kopet-Dagh Basin, NE Iran. J Pet Geol. 1993;16:55-72. https://doi.org/10.1111/j.1747-5457.1993.tb00730.x.

Moussavi-Harami R, Mahboubi A, Nadjafi M, Brenner RL, Mortazavi M. Mechanism of calcrete Formation in the Lower Cretaceous (Neocomian) fluvial deposits, northeastern Iran based on petrographic, geochemical data. Cretaceous Res. 2009;30:1146-56.

Owen G. Experimental soft-sediment deformation: structures formed by the liquefaction of unconsolidated sands and some ancient examples. Sedimentology. 1996;43(2):279-93.

Posamentier HW, Davies RJ, Cartwright JA, Wood HW. Seismic geomorphology-an overview. In: Davies RJ, Posamentier HW, Wood LJ, Cartwright JA, editors. Seismic geomorphology: applications to hydrocarbon exploration and production, vol. 277. Geol Soc Lond Spec Publ; 2007. 1-14.

Posamentier HW. Low stand alluvial bypass systems: incised vs. unincised. AAPG Bull. 2001;85:1771-93.

Ramazani-Oomali R, Shahriari S, Hafezi-Moghaddas N, Omidi P, Eftekharnejhad J. A model for active tectonics in Kopet-Dagh (North-East Iran). World Appl Sci J. 2008;3:312-6. 
Robert AMM, Letouzey J, Kavoosi MA, Sherkati Sh, Muller C, Verges $\mathrm{J}$, et al. Structural evolution of the Kopeh-Dagh fold-and-thrust belt (NE Iran) and interactions with the South Caspian Sea Basin and Amu Darya Basin. Mar Pet Geol. 2014;57:68-87. https://doi. org/10.1016/j.marpetgeo.2014.05.002.

Røe S-L. Cross-strata and bedforms of probable transitional dune to upper-stage plane-bed origin from a Late Precambrian fluvial sandstone, northern Norway. Sedimentology. 1987;34(1):89-101

Ruttner AW. The Triassic of Aghdarband (AgDarband), NE-Iran, and its preTriassic frame. Abhandlungen der Geologischen Bundesanstalt. 1991;38:252.

Ruttner AW. Southern borderland of Triassic Laurasia in northeast Iran. Geol Rundsch. 1993;82:110-20.

Saadati H, Al-Iessa HJ, Alizadeh B, Tarhandeh E, Jazayeri MH, Bahrami $\mathrm{H}$, et al. Geochemical characteristics and isotopic reversal of natural gases in eastern Kopeh-Dagh, NE Iran. Mar Pet Geol. 2016;78:76-87.

Siehl A. Structural setting and evolution of the Afghan orogenic segment-a review. In: Brunet M-F, McCann T, Sobel ER, editors. Geological evolution of Central Asian Basins and the Western Tien Shan Range. Geol Soc Lond Spec Publ; 2015. 427.

Stocklin J. Structural correlation of the Alpine ranges between Iran and Central Asia. Société Géologique de France, Mémoires Hors Serie. 1977;8:333-53.

Taheri J, Fürsich FT, Wilmsen M. Stratigraphy, depositional environments and geodynamic significance of the Upper Bajocian-Bathonian Kashafrud Formation, NE Iran. In: Brunet M-F, Wilmsen M, Granath JW, editors. South Caspian to Central Iran Basins. Geol Soc Lond Spec Publ 2009;312: 205-218. 10.144/SP312.10.

Thomas JC, Cobbold ER, Shein VS, Ledouaran S. Sedimentary record of late Paleozoic to Recent tectonism in central Asia: analysis of subsurface data from the Turan and south Kazak domains. Tectonophysics. 1999;313(3):243-63. https://doi.org/10.1016/S0040 -1951(99)00208-5.

Torrado L, Mann P, Bhattacharya J. Application of seismic attributes and spectral decomposition for reservoir characterization of a complex fluvial system: case study of the Carbonera Formation, Llanos foreland basin. Colomb Geophys. 2014;79(5):221-30. https://doi.org/10.1190/geo2013-0429.1.

Ulmishek GF. Petroleum geology and resources of the Amu-Darya Basin Turkmenistan Uzbekistan Afghanistan and Iran. Reston: U.S Geological Survey Bulletin; 2004. p. 2201-H.
VZG Geological structure and oil and gas potential of the southern part of the Amu Darya Basin. In: Klett TR, Ulmishek GF, Wandrey CJ, Agena WF, U.S. Geological Survey-Afghanistan Ministry of Mines and Industry Joint Oil and Gas Resource Assessment Team. (eds) Assessment of undiscovered technically recoverable conventional petroleum resources of Northern Afghanistan. United States Geological Survey, Open-File Report 1253; 2004.

Wang Y, Eichkitz CG, Schreilechner MG, Heinemenn G, Davis JC, Gharsalla M. Seismic attributes for description of reef growth and channel system evolution-case study of Intisar E Libya. Interpretation. 2016;4(1):SB1-11. https://doi.org/10.1190/INT-2015-0017.1.

Wood LJ. Quantitative seismic geomorphology of Pliocene and Miocene fluvial systems in the northern Gulf of Mexico. J Sediment Res. 2007;77:713-30. https://doi.org/10.2110/jsr.2007.068.

Yixin Y, Jinyin Y, Junzhang Z, Feng L, Chongzhi T, Xiaolong X, Hang W. Division and resources evaluation of hydrocarbon plays in the Amu Darya basin, central Asia. Pet Explor Dev. 2015;42(6):819-26

Zanchetta S, Berra F, Zanchi A, Bergomi M, Caridroit M, Nicorab A, et al. The record of the Late Palaeozoic active margin of the Palaeotethys in NE Iran: constraints on the Cimmerian orogeny. Gondwana Res. 2013;24(3-4):1237-66.

Zanchi A, Zanchetta S, Berra F, Mattei M, Garzanti E, Molyneux S, et al. The Eo-Cimmerian (Late? Triassic) orogeny in North Iran. Geol Soc Lond Spec Publ 2009;312: 31-55.

Zanchi A, Zanchetta S, Balini M, Ghassemi MR. Oblique convergence during the Cimmerian collision: evidence from the Triassic Aghdarband Basin, NE Iran. Gondwana Res. 2016;38:149-70. https ://doi.org/10.1016/j.gr.2015.11.008.

Zand-Moghadam H, Moussavi-Harami R, Mahboubi A, Aghaei A. Lithofacies and sequence stratigraphic analysis of the Upper Jurassic siliciclastics in the eastern Kopet-Dagh Basin, NE Iran. J Afr Earth Sci. 2016;117:48-61.

Zeng H. Stratal slicing: benefits and challenges. Lead Edge. 2010;29(9):1040-7. https://doi.org/10.1190/1.3485764.

Zeng H, Hentz TF. High-frequency sequence stratigraphy from seismic sedimentology: applied to Miocene, Vermilion Block 50, Tiger Shoal area, offshore Louisiana. AAPG Bull. 2004;88:153-74.

Zhu H, Zeng H, Yang X, He Y. Seismic interpretation of tectonic and palaeogeomorphologic controls on sediment dispersal patterns in a continental rift basin: a case study from the Bohai Bay Basin, China. Interpretation. 2013;1(1):1-13. https://doi.org/10.1190/ INT-2012-0001.1. 